\title{
Pharmacotherapy of Acute Lung Injury and Acute Respiratory Distress Syndrome
}

\author{
Krishnan Raghavendran ${ }^{\star}, 1,2$, Gloria S. Pryhuber ${ }^{3,4}$, Patricia R. Chess ${ }^{3}$, Bruce A. \\ Davidson $^{2}$, Paul R. Knight ${ }^{2}$, and Robert H. Notter ${ }^{3,4}$ \\ 1 Department of Surgery, State University of New York (SUNY) at Buffalo, Buffalo, NY \\ 2Department of Anesthesiology, State University of New York (SUNY) at Buffalo, Buffalo, NY \\ 3Department of Pediatrics, University of Rochester, Rochester, NY, USA \\ 4Department of Environmental Medicine, University of Rochester, Rochester, NY, USA
}

\section{Abstract}

Acute lung injury (ALI) and the acute respiratory distress syndrome (ARDS) are characterized by rapid-onset respiratory failure following a variety of direct and indirect insults to the parenchyma or vasculature of the lungs. Mortality from ALI/ARDS is substantial, and current therapy primarily emphasizes mechanical ventilation and judicial fluid management plus standard treatment of the initiating insult and any known underlying disease. Current pharmacotherapy for ALI/ARDS is not optimal, and there is a significant need for more effective medicinal chemical agents for use in these severe and lethal lung injury syndromes. To facilitate future chemical-based drug discovery research on new agent development, this paper reviews present pharmacotherapy for ALI/ARDS in the context of biological and biochemical drug activities. The complex lung injury pathophysiology of ALI/ ARDS offers an array of possible targets for drug therapy, including inflammation, cell and tissue injury, vascular dysfunction, surfactant dysfunction, and oxidant injury. Added targets for pharmacotherapy outside the lungs may also be present, since multiorgan or systemic pathology is common in ALI/ARDS. The biological and physiological complexity of ALI/ARDS requires the consideration of combined-agent treatments in addition to single-agent therapies. A number of pharmacologic agents have been studied individually in ALI/ARDS, with limited or minimal success in improving survival. However, many of these agents have complementary biological/biochemical activities with the potential for synergy or additivity in combination therapy as discussed in this article.

\section{Keywords}

ARDS; ALI; inflammatory lung injury; lung injury therapy; anti-inflammatory therapy; surfactant therapy; INO therapy; anti-oxidants; pharmacotherapy

\section{INTRODUCTION}

Clinical acute lung injury (ALI) and the acute respiratory distress syndrome (ARDS) can arise in patients of all ages from direct or indirect insults that induce pulmonary inflammation, damage the cells of the alveolocapillary membrane, and lead to severe acute respiratory failure. The American-European Consensus Committee (AECC) in 1994 defined clinical ALI as

*Address correspondence to this author at the Department of Surgery, State University of New York (SUNY) at Buffalo, 462 Grider Street, DK Miller Building, suite 316, Buffalo, NY 14214; E-mail: kr25@buffalo.edu. 
respiratory failure of acute onset with $\mathrm{PaO}_{2} / \mathrm{FiO}_{2}$ ratio $\leq 300 \mathrm{mmHg}$ (regardless of the level of positive end expiratory pressure, PEEP), bilateral infiltrates on frontal chest radiograph, and a pulmonary capillary wedge pressure $<18 \mathrm{mmHg}$ (if measured) or no evidence of left atrial hypertension [1]. ARDS was defined identically except for a lower limiting value of $<200$ mmHg for $\mathrm{PaO}_{2} / \mathrm{FiO}_{2}$ [1]. The AECC definitions of ALI/ARDS are widely-used and simple to apply, but also have serious deficiencies in discrimination. There is often not a good correlation between these broad clinical definitions and diffuse alveolar damage (DAD), which is widely considered to be a major characteristic histological feature of ALI/ARDS [2]. The AECC definitions also do not take into consideration variables such as the mode of ventilation and the level of PEEP, which can significantly influence oxygenation. The AECC definitions of ALI/ARDS are thus frequently supplemented by lung injury or critical care scores like the Murray score [3] or the APACHE II [4] in adults, and the PRISM (Pediatric RISk of Mortality score) [5,6], PIM (Pediatric Index of Mortality score) [7], or Oxygenation Index [8] in children. An alternative definition of ARDS by a recent Delphi consensus panel of senior investigators includes PEEP restrictions in defining hypoxemia, radiographic criteria for air space disease in two or more quadrants, and requires either quantitative compliance abnormalities or the presence of a predisposing condition [9]. Although the Delphi definition is more specific than the AECC criteria, it has been reported to be less sensitive [10].

Although ALI and ARDS encompass a broad spectrum of etiologies, it is important to consider specific causes of lung injury in targeting therapeutic agents. In particular, it is relevant to distinguish between ALI/ARDS from direct pulmonary causes as opposed to systemic (indirect, non-pulmonary) causes. As reviewed elsewhere [1,11-17], common direct pulmonary causes of ALI/ARDS include lung viral or bacterial infections, gastric aspiration, blunt thoracic trauma with lung contusion, meconium aspiration (infants), near-drowning, thoracic radiation, hyperoxia, and the inhalation of smoke or other toxicants. Common indirect (systemic) causes of ALI/ARDS include sepsis, closed space burn injury, hypovolemic shock, non-thoracic trauma, multiple transfusions, and pancreatitis. The pathology of ALI/ARDS is particularly complex in systemic insults like sepsis, where multi-organ involvement is common and extra-pulmonary inflammation is severe and pervasive as reflected by systemic inflammatory response syndrome (SIRS), multiple organ dysfunction syndrome (MODS), or multiple organ failure (MOF) $[4,18,19]$. The severe systemic pathology in indirect forms of ALI/ARDS has the potential to significantly limit the effectiveness of pharmacological and other therapies that target pulmonary pathology compared to the case of ALI/ARDS caused by direct lung injury. As one example, post-hoc analyses in two recent clinical trials of surfactant therapy in ALI/ARDS suggest greater efficacy in direct as opposed to indirect forms of these syndromes [20,21].

Regardless of definition, ALI and ARDS affect a large number of patients and have a poor prognosis. The incidence of ALI/ARDS has been variably reported to be 50,000-190,000 cases per year in the United States [1,11-17,22]. The incidence of ALI in two recent studies has been estimated at 22-86 cases per 100,000 persons per year [16,17], with 40-43 percent of these patients having ARDS [16]. These studies primarily considered adults, and the incidence of ALI/ARDS is lower at 2-8 cases per 100,000 persons per year in the pediatric age group [23-26]. Survival statistics for patients with ALI/ARDS vary with lung injury etiology and age, but overall mortality rates in both adult and pediatric patients remain very substantial at $30-50 \%$ despite sophisticated intensive care [1,11-17,22,24-31]. The significance of distinguishing between the two clinical syndromes in a practical sense is uncertain, since a meta-analysis of 102 studies prior to 1996 suggested little or no difference in mortality rates between patients meeting criteria for ALI compared to ARDS [12]. This was also the conclusion in the recent NEJM article by Rubenfeld et al. [16], which reported mortality rates of $38.5 \%$ for ALI and $41 \%$ for ARDS, with an estimated 74,500 deaths per year and an aggregate 3.6 million hospital days of care in the United States. 
There is clearly a significant need for improved treatments for ALI/ARDS in all age groups, and this review focuses on medicinal chemical interventions. Major emphasis in this article is on reviewing current medicinal chemical agents in the context of their biochemical and biological activities directed against specific aspects of the pathophysiology of acute inflammatory pulmonary injury in ALI/ARDS. The material presented is not only relevant for current clinical pharmacotherapy, but also will hopefully help to facilitate future work on chemistry-based drug discovery and the development of active new medicinal chemical agents for ALI/ARDS based on the targeting of specific biological and biochemical aspects of pathophysiology.

\section{DIFFICULTIES OF DEVELOPING AND TESTING THERAPIES IN ALI/ARDS}

Over the past two decades, a variety of interventions and intensive care strategies have been used in treating patients with ALI/ARDS. The current standard of clinical care for ALI/ARDS includes mechanical ventilation with lung protective strategies, coupled with judicious fluid management, adjunct nutritional support, and specific treatment of any known underlying cause of injury or disease. The only intervention to date that has clearly showed a survival benefit in controlled studies in adults with ARDS has been the adoption of low tidal volume ventilation strategies (6-8 ml/kg bodyweight) [32], an advance that is non-pharmacologic in nature. In addition, exogenous surfactant therapy with an active bovine-derived drug (Infasurf) has recently been shown to improve survival in pediatric patients up to age 21 with direct pulmonary ALI/ARDS [33].

A major difficulty in testing and evaluating medicinal chemical therapies for ALI/ARDS is that clinical studies on agent efficacy in these syndromes are complicated by their multiple etiologies and heterogeneous cohort of affected patients (see preceding section). Although some of this heterogeneity can be reduced by considering direct versus indirect causes of ALI/ ARDS, patients in both categories still vary in age and may also have significant co-morbid conditions such as diabetes, alcohol abuse, or other chronic pathologies particularly in the case of adults. Even if co-morbidities and extra-pulmonary pathology are absent or relatively minimal (e.g., as in otherwise healthy patients with direct forms of lung injury), the multifaceted pathophysiology of pulmonary injury itself is a complicating factor in efficacy assessments. An individual pharmacologic agent may in fact be effective in mitigating its intended target of pathology, but benefits to survival and other long term clinical outcomes may be obscured by remaining aspects of pathology. All these considerations complicate the design and analysis of clinical trials and reduce their resolving power. In general, evaluating therapies in ALI/ARDS requires multi-center studies of substantial size, with patient populations and outcome variables controlled with as much focus as possible. More complete discussion of factors affecting the design of clinical trials for testing single-agent and combination therapies in ALI/ARDS is given elsewhere [34].

Although developing and testing medicinal chemical interventions for clinical ALI/ARDS is certainly challenging, there is reason for optimism about the potential for more effective therapies of this kind. A significant amount of scientific information has now accrued concerning the mechanistic pathophysiology of acute and chronic pulmonary injury and inflammation, and this has identified a number of biological targets for pharmacologic agents. Moreover, extensive on-going research on acute and chronic lung injury at the cellular and molecular level can be expected to identify additional agents and targets for specific pharmacology as time progresses. The remainder of this article reviews current medicinal chemical agents used or potentially applicable for ALI/ARDS. Many of these agents have been shown to have significant beneficial effects in laboratory and animal model research on lung injury, although benefits to survival in human studies, particularly in adults, have not yet been seen. In at least some cases, this may reflect the limited resolving power of clinical trial 
assessments in ALI/ARDS described above. In addition, factors relating to drug activity or delivery can help to explain the lack of clinical efficacy of specific agents, as discussed later for some exogenous surfactants.

The complex multifaceted pathology of ALI/ARDS may ultimately require mechanism-based combination interventions instead of single-agent therapy, as reviewed in detail by Pryhuber et al. [34]. Defining combination therapies for ALI/ARDS requires integrated basic and clinical research. Mechanistic studies of activity and interactions in animal and cell models are essential in screening, refining, and focusing specific combination therapies for ultimate clinical testing [34]. Combination therapy approaches in ALI/ARDS could include the use of multiple pharmacological agents together, as well as multimodal strategies that involve drug therapy plus non-pharmacologic interventions such as the use of specific modes or protocols of mechanical ventilation to enhance alveolar recruitment and minimize ventilator-induced lung injury) [32,34-46]. This article focuses on pharmacological agents, and detailed review of nondrug treatments such as low tidal volume and lung protective ventilation strategies, prone positioning, and conservative fluid management is not included.

\section{MEDICINAL CHEMICAL TARGETS IN THE PATHO-PHYSIOLOGY OF ALI/} ARDS

Rational medicinal chemical drug discovery and development for ALI/ARDS depends on pathophysiological understanding. Although ALI/ARDS is sometimes subdivided into early, mid, and late periods of pathology, pharmacotherapy for these syndromes is discussed here in terms of two major phases: the acute exudative phase and the later fibroproliferative phase. Occurring within 12-72 hours of the initiating lung injury stimulus, the exudative phase of ALI/ARDS is initially characterized by prominent interstitial and alveolar edema in association with an increased permeability in the alveolocapillary membrane (capillary endothelial cells and alveolar type I epithelial cells) that normally maintains a tight barrier and electrolyte balance [47-50]. Over the next 3-7 days, further alveolocapillary damage occurs, with denuding of basal lamina and the formation of intra-alveolar hyaline membranes containing plasma proteins, fibrin and cellular debris. Complement and coagulation cascades are activated, and multiple inflammatory cytokines/chemokines and reactive oxygen/nitrogen species are released [51]. Pulmonary blood flow and perfusion are reduced in acute exudative ALI/ARDS by thrombus formation, intravascular sequestration of leukocytes and platelets, and hypoxiainduced vasoconstriction. Surfactant activity can be impaired by several mechanisms including interactions with serum proteins and other inhibitors in edema [52-55]. Surfactant metabolism, including the production of surfactant apoproteins, may also be disrupted if alveolar type II cells are injured or become altered by the pulmonary inflammatory response. Potential targets for therapies in the acute exudative phase of ALI/ARDS include general hypoperfusion as well as ventilation/perfusion mismatching, surfactant dysfunction, arterial hypoxemia and edema, inflammation, oxidant injury, and cellular injury to the alveolar epithelium and capillary endothelium (Table 1).

The acute phase of ALI/ARDS is generally followed in survivors by a 1-3 week period of fibroproliferation and organization of previously deposited intra-alveolar and interstitial exudates [51]. In the fibroproliferative phase of ALI/ARDS, type II cells proliferate and line the alveolar wall, re-covering the basement membrane and migrating over organizing intraalveolar hyaline membranes. These type II cells can present a chronic source of proinflammatory mediators (for details on the spectrum of inflammatory mediators in acute and chronic lung injury see Ref [56]). There is also proliferation and migration of fibroblasts into intra-alveolar exudates, along with differentiation of fibroblasts into myofibroblasts. Collagen-rich extracellular matrix material is deposited in the pulmonary interstitium, and fibrosis can start to become apparent. Alveoli are lost by accumulation of connective tissue 
within septal walls and by dropout as collapsed distal airways and airsacs become sealed by organizing fibrin and hyperplastic epithelium. Vascular and perivascular smooth muscle cell proliferation also occurs, and pulmonary vascular area is reduced leading to pulmonary hypertension. In some areas of lung, there can be complete destruction of small arteries (obliterative endarteritis). Chronic inflammatory foci rich in polymorphonuclear cells are also typically present in the lung interstitium, potentially augmenting the destruction of neighboring alveolar structure.

The fibroproliferative phase of ALI/ARDS either slowly resolves, progresses, or remains static. The incidence of fibrosis following ARDS is noteworthy. One study using high-resolution computed tomography and lung function testing demonstrated pulmonary fibrosis in 13 of 15 patients examined 6-10 months after ARDS [57]. The extent of fibrotic pathology correlated with the severity of ARDS ( $\mathrm{p}<0.01)$ and with the duration of mechanical ventilation with peak inspiratory pressures greater than $30 \mathrm{mmHg}(\mathrm{p}<0.05)$ or $>70 \%$ inspired oxygen $(\mathrm{p}<0.01)$ [57]. This suggests that acute pulmonary injury impacts the development of fibrosis, and that ventilator- and hyperoxia-induced injury may be important factors. Even in the absence of clear fibrosis, it is common for patients recovering from ALI/ARDS to demonstrate reduced exercise tolerance and abnormalities in pulmonary function tests including diffusion capacity [58]. In contrast to therapies in the exudative phase of ALI/ARDS, interventions in the fibroproliferative phase must address pathophysiological elements of remodeling, repair and fibrosis [59-64] (summarized in Table 2). Details on specific pharmacological agents for the exudative and fibroproliferative phases of ALI/ARDS are given in following sections.

\section{PHARMACOTHERAPY FOR VENTILATION-PERFUSION INDUCED- HYPOXEMIA IN EXUDATIVE ALI/ARDS}

One of the primary goals in treating acute respiratory failure in the exudative phase of ALI/ ARDS is to improve alveolar ventilation $\left(\mathrm{V}_{\mathrm{A}}\right)$ and the ratio to capillary perfusion $\left(\mathrm{Q}_{\mathrm{c}}\right)$, i.e. to enhance $\mathrm{V}_{\mathrm{A}} / \mathrm{Q}_{\mathrm{c}}$ matching. Selected pharmacologic agents for improving $\mathrm{V}_{\mathrm{A}} / \mathrm{Q}_{\mathrm{c}}$ matching and arterial oxygenation are summarized in Table 3 . These include inhaled vasodilators to increase blood flow to ventilated alveoli, selective vasoconstrictors to potentiate hypoxic vasoconstriction in non-ventilated regions of lung, exogenous surfactants to reduce alveolar surface tension and increase alveolar ventilation, anti-coagulants to antagonize thrombus formation and increase pulmonary blood flow, and $\beta-2$ agonists to reduce edema. A number of these agents have been used and tested clinically in single-agent therapy for ALI/ARDS, but a majority of them have not been examined in any detail in combination therapies.

\subsection{Vasoactive Agents for Treating Acute Exudative ALI/ARDS}

The ability to titrate dosing and the degree of pulmonary selectivity are major considerations in selecting vasoactive drugs for acute respiratory failure. Relatively few vasoactive agents have been identified that generate therapeutic pulmonary actions without significant systemic side effects if given intravenously [65]. The development of inhaled drugs such as nitric oxide and prostacyclin that can directly target the pulmonary vasculature in mechanically-ventilated patients has reduced systemic side effects and led to improved efficacy.

4.1.1. Inhaled Nitric Oxide (INO)—Nitric oxide, a naturally-occurring product identical to endothelial-derived relaxing factor [66-68], is an important endogenous mediator in several physiological processes in vivo. One of its most important cardiovascular actions is potent vasodilation, which results from decreased calcium in smooth muscle cell cytoplasm following an NO-dependent increase in cyclic-GMP. The activity of NO can be pharmacologic as well as physiologic. Inhaled NO (INO) affects gas exchange by increasing blood flow in ventilated areas to improve $V_{A} / Q_{c}$ matching. Due to its high affinity for hemoglobin, INO is active 
principally in ventilated lung regions with relatively little diffusion into neighboring nonventilated tissues. INO has been used in the therapy of several pediatric and adult lung diseases ([69-71] for review). A major established therapeutic use of INO is in pulmonary hypertension of the newborn [69,72-74]. INO has also been shown to reduce pulmonary artery pressures and/or pulmonary vascular resistance in a number of animal models of acute pulmonary injury [75-80], making it relevant for patients with ALI/ARDS. Clinical studies have shown that INO improves arterial oxygenation and reduces pulmonary artery pressure in adults with ARDS [81-89] and in infants or children with acute respiratory failure [90-96]. The efficacy of INO has also been reported to be additive with those of PEEP [97] and patient prone positioning [98].

Michael et al. [87] studied 40 patients with ARDS, and reported improved oxygenation for the first 24 hours in those receiving INO plus conventional therapy compared to conventional therapy alone. The double-blind trial of Dellinger et al. [85] from the multi-center INO in ARDS Study Group involved 177 patients with ARDS and compared 3 dosages of INO with placebo. Several measures of acute lung function (e.g., $\mathrm{PaO}_{2}, \mathrm{FiO}_{2}, \mathrm{PaO}_{2} / \mathrm{FiO}_{2}$ ratio, PEEP, mean airway pressure) were improved in patients receiving INO [85]. However, Dellinger $e t$ al. [85] reported no difference in mortality rate or in the number of days alive following mechanical ventilation in patients treated with INO. The authors suggested that "larger phase III studies are needed to ascertain if the acute physiologic response (to INO) can lead to altered clinical outcome."

One drawback to INO therapy is that some patients require a prolonged treatment and withdrawal course, likely due in part to down-regulation of endogenous NO production. Since therapeutic NO is currently delivered primarily through mechanical ventilation circuits, this necessitates prolonged ventilation. However, recent studies administering INO through nasal cannula circuits suggest that alternative delivery systems could allow more gradual weaning of the gas and earlier extubation [99]. Adverse effects of NO therapy such as methemoglobinemia, production of peroxynitrate, increased pulmonary edema and rebound pulmonary hypertension have also been noted in some clinical studies [81,86,87]. A Cochrane Library review on the use of INO for treating acute hypoxic respiratory failure identified five studies assessing over 500 patients that demonstrated no statistically significant effect of INO on mortality but indicated a transient improvement in oxygenation [100]. The authors of the Review called for future INO studies "to stratify patients by their primary disorder, to assess the importance of combined modalities, and to specifically evaluate clinically relevant outcomes [100]."

Further vascular smooth muscle relaxation and reduction in pulmonary hypertension may be accomplished with selective phosphodiesterase inhibitors such as sildenafil and more recent inhibitors of phosphodiesterase (PDE) V [101,102]. These inhibitors reduce cGMP metabolism and hence may act in combination with nitric oxide to enhance smooth muscle relaxation and reduce pulmonary hypertension [103]. Case reports and animal research support the efficacy of such drugs especially in refractory or INO-dependent pulmonary hypertension $[104,105]$. The selectivity of PDE inhibitors appears to be in part dose dependent, with higher doses more likely to induce systemic hypotension. The PDE III inhibitor milrinone has also been observed to reduce acute pulmonary hypertension [106].

4.1.2. Prostacyclin and other Vasodilatory Prostaglandins-Prostacyclin is a microcirculatory vasodilator and inhibitor of platelet aggregation used for several indications in neonatal and adult medicine. When aerosolized, its vasodilatory action in ventilated areas should be similar to INO in improving $\mathrm{V}_{\mathrm{A}} / \mathrm{Q}_{\mathrm{c}}$ matching without promoting systemic hypotension. Consistent with this, aerosolized prostacyclin improved acute respiratory function to the same degree as INO in several studies in patients with ARDS [107-109]. 
Another vasodilatory prostaglandin, $\mathrm{PGE}_{1}$, also has been shown to give improvements similar to those of INO when delivered by aerosol to patients with ARDS [110]. These results suggest that aerosolized prostacyclin or similar drugs could be viable therapeutic alternatives to INO. Additionally prostacyclin may have some advantages over NO as it is easier to administer and has harmless metabolites. However it is more expensive and has not shown any survival benefit in human trials [107].

\subsubsection{Selective Vasoconstrictors Used in Combination with Inhaled}

Vasodilators - The activity of INO and other inhaled vasodilators in treating acute respiratory failure in ALI/ARDS may be further enhanced by specific vasoconstrictors (e.g., $[65,111,112]$ for review). The mechanistic rationale for this is that selective vasoconstrictive drugs can reinforce the natural hypoxic vasoconstriction of the pulmonary vasculature in poorly ventilated regions. In principle, selective constriction of blood vessels in under-ventilated alveoli allows a larger fraction of pulmonary blood flow to be redirected to ventilated areas to improve $\mathrm{V}_{\mathrm{A}} / \mathrm{Q}_{\mathrm{c}}$ matching. The use of vasoconstrictive agents also has the potential for negative effects, since excessive or inappropriate vasoconstriction would further impair an already compromised gas exchange process. Several clinical studies have shown that co-administration of INO and almitrine bismesylate, a selective pulmonary vasoconstrictor, can enhance the efficacy of INO in improving arterial oxygenation or reducing the level of mechanical ventilatory support in patients with ARDS [112-118]. Caution is warranted with the use of almitrine because of a potential increase in pulmonary arterial pressure and right ventricular loading [119]. However, promising results from the concurrent use of INO and almitrine support the concept of using rational combinations of vasoactive agents in treating ALI/ARDS. Phenylephrine has also been reported to generate improvements in acute respiratory function in ARDS patients responding to INO [120], although the mechanisms involved have been questioned [121].

\subsection{Exogenous Surfactant Therapy for Acute Phase ALI/ARDS}

The rationale for exogenous surfactant therapy in ALI/ARDS is primarily to reverse surfactant dysfunction (inhibition), although surfactant deficiency is also treated by this intervention. Abnormalities in surfactant in lung lavage from patients with ALI/ARDS are well-documented [122-129], and exogenous surfactant therapy has a strong rationale based on extensive biophysical research showing that raising surfactant concentration can overcome inhibition by endogenous compounds present in injured lungs ([52,53,130-132] for review). In addition, the ability of exogenous surfactants to improve pulmonary mechanics and function has been established in multiple animal models of ALI/ARDS including acid aspiration [133-135], meconium aspiration [136-139], anti-lung serum [140], bacterial or endotoxin injury [141146], vagotomy [147], hyperoxia [148-152], in vivo lung lavage [153-158], N-nitroso-Nmethylurethane (NNNMU) injury [159-161], and viral pneumonia [162,163]. Consistent with these laboratory findings, surfactant therapy has been shown to be successful in infants with ARDS-related lung injury associated with meconium aspiration or pneumonia [164-172], as well as in children and young adults with ALI/ARDS [33,173,174]. Particularly impressive is the recent double-blind, placebo-controlled study by Willson et al. [33] in 153 pediatric patients up to age $21 \mathrm{yrs}$ with ALI/ARDS, which demonstrated not only lung functional benefits but also a substantial improvement in survival following treatment with the bovine-derived surfactant Infasurf®. Aside from low tidal volume ventilation as noted earlier [32], this is one of the few controlled studies to show substantive survival improvements in patients with ALI/ ARDS.

Several small pilot studies have also documented improved respiratory function (oxygenation) in adults with ALI/ARDS [175-179]. However, controlled clinical trials in adults have been less successful. By far the largest prospective controlled study of surfactant therapy in adults 
with ARDS was definitively negative [180]. Anzueto et al. [180] administered nebulized Exosurf® vs. placebo to 725 adults with ARDS secondary to sepsis and found no improvement in any measure of oxygenation and no effect on morbidity or mortality. However, interpretation of these negative results is confounded because both laboratory and clinical studies have documented that Exosurf® has low activity compared to animal-derived surfactants [181190], and this surfactant is no longer marketed in the United States. In addition, aerosolization has not been shown to be as effective as airway instillation in delivering surfactant. Gregory et al. [191] reported only small benefits in oxygenation in a controlled trial in adults with ARDS who received four $100 \mathrm{mg} / \mathrm{kg}$ doses of Survanta®, but with no overall advantage in survival in the 43 surfactant-treated patients studied. However, this exogenous surfactant contains only very small amounts of surfactant protein (SP)-B [192], which is known to be the most active apoprotein in native surfactant [193-201]. A more recent study by Spragg et al. [21] using recombinant SP-C surfactant (Venticute $\AA$ ) in adults with ARDS showed immediate improvements in oxygenation, but no improvement in duration of mechanical ventilation, lengths of stay, or mortality. Post-hoc analysis did suggest, however, that the response in the subgroup of patients with ARDS due to "direct lung injury" was positive [21], and a followup prospective study in this category of patients is currently underway. Exogenous surfactant therapy in ALI/ARDS requires the use of the most active clinical surfactant drugs plus effective delivery methods. In addition to animal-derived surfactants such as Infasurf, highly-active new synthetic lipid/peptide lung surfactants are currently being developed that have significant potential advantages in manufacturing, economy, and purity compared to biological products [202-207]. Such synthetic surfactants include preparations with novel physicochemical properties like phospholipase-resistance [203-207], which may be of particular importance in ALI/ARDS where these lytic enzymes can be elaborated in high concentrations in the interstitium and alveoli [208-214].

\subsection{INO Plus Exogenous Surfactant in Combination Therapy}

The rationale for combination therapy with INO and exogenous surfactant is based on their complementary mechanisms of action in improving ventilation/perfusion matching and gas exchange. INO dilates the vasculature in ventilated lung units, while surfactant improves ventilation by decreasing surface tension and enhancing alveolar stability and recruitment. Exogenous surfactant therapy would theoretically increase the ventilated lung area accessible to INO, while the latter would increase the perfusion of these ventilated areas. Additive improvements in lung function from the simultaneous use of INO and exogenous surfactant have been demonstrated in premature surfactant-deficient lambs with congenital diaphragmatic hernia [215], as well as in animal models of ALI/ARDS [216-221]. A stepwise, multiple regression analysis of neonates with hypoxic respiratory failure being weaned from INO has demonstrated that therapeutic surfactant significantly enhanced oxygenation reserve [222]. Clinical benefits have been reported from exogenous surfactant therapy and INO in a small case series in full-term infants with severe acute respiratory failure [223]. These findings support more extensive study of combination therapy with surfactant and INO in ALI/ARDS. This is also the conclusion of a review of newborns $<5$ days old and $\geq 35$ weeks gestation diagnosed with hypoxemic respiratory failure (oxygenation index $>15$ ) from meconium aspiration, sepsis/pneumonia or persistent pulmonary hypertension in the eras preceding (1993-1994) and following (1996-1997) the simultaneous availability of high frequency oscillatory ventilation, INO and exogenous surfactant [224]. The simultaneous availability of these therapies was associated with a reduced percentage of infants requiring rescue therapy with ECMO (42.8\% vs. $27.7 \%$ ) that was not fully attributable to the reported efficacy of the individual agents alone [224]. Prospective controlled clinical trials on the combined use of INO and exogenous surfactant have not yet been done in pediatric or adult patients with ALI/ARDS. 


\subsection{Agents to Enhance Pulmonary Blood Flow by Reducing Intravascular Coagulation}

Therapies that reduce vascular obstruction have the potential for synergy with agents that dilate the pulmonary vasculature (INO) or increase alveolar ventilation (exogenous surfactant) [225]. Pulmonary vascular obstruction can occur in patients with ALI/ARDS from leukocyte and platelet aggregation and later fibrin deposition [226]. Intravascular coagulation can reduce blood flow, decrease the functional area of the pulmonary vascular bed, and lead to increased mismatching of ventilation and perfusion. In addition, intra-alveolar coagulation may promote fibrin deposition and provide a matrix for organizing inflammatory cells and fibroblasts contributing to the later development of pulmonary fibrosis. Administration of the anticoagulants tissue factor pathway inhibitor (TFPI) or site-inactivated factor VIIa has been reported to protect gas exchange and compliance, reduce pulmonary edema and hypertension, and preserve renal function in a baboon model of gram-negative sepsis [227]. Systemic proinflammatory cytokine responses including production of interleukin (IL)-6 were also reduced by anticoagulant therapy [227]. A preliminary report of a small Phase 2 clinical trial of septic patients treated with TFPI indicated reduced cytokine levels and a roughly $35 \%$ survival advantage in the ARDS subgroup in association with a measurable anti-coagulant effect [228]. Mortality has also been found to be significantly reduced in a large study of patients with severe sepsis treated with anti-thrombotic protein C (APC), a selective endogenous anticoagulant that is rapidly depleted in septic shock [229]. Additionally healthy patients treated with activated protein $\mathrm{C}$ have shown a decrease in lung inflammation and inhibition of coagulation after endotoxin exposure [230,231]. A multicenter phase II study of activated protein C in ALI/is expected to be completed in 2008.

\subsection{Drugs to Improve Alveolar Fluid Clearance}

A good deal of recent interest has focused on ways to clear alveolar edema during the acute phase of ARDS. The clearance of fluid from the alveolar space has been shown to be crucial for the successful resolution of ARDS and associated respiratory failure [232-234]. Patients with ARDS have impaired alveolar fluid clearance [232,233], and those better able to clear extravascular lung water (EVLW) demonstrate a survival advantage [233,234]. Salbutamol or related $\beta-2$ agonists have the potential to improve alveolar fluid clearance in ARDS by upregulating sodium transport mechanisms on the alveolar epithelial cells $[49,232,235]$. In addition, $\beta-2$ agonists cause pulmonary vasodilation and reduce the edema-promoting hydrostatic driving force for fluid transport across capillaries [236]. Based on data in $\beta-2$ knockout mice [237] and volunteers at risk for high altitude pulmonary edema [238], a single center double-blind study (BALTI) was recently conducted on the use of salbutamol in patients with ARDS [239]. Results showed that patients receiving salbutamol had significantly lower levels of EVLW [239]. As a result of these findings, the ARDS network is now initiating a multi-center randomized, controlled study using $\beta$-2 agonists in ALI/ARDS [234].

\section{PHARMACOTHERAPY TARGETING INFLAMMATION OR OXIDANT INJURY IN EXUDATIVE ALI/ARDS}

Over-exuberant inflammation is generally a prominent feature of the exudative phase of ALI/ ARDS. The overproduction of pro-inflammatory cytokines, chemokines, growth factors, and reactive oxygen/nitrogen species by activated leukocytes and resident lung cells can sometimes be more harmful than the initial stimulus causing lung injury. Increased levels of proinflammatory mediators and reactive chemical species have been found in lavage fluid, plasma, and blood cells from patients with ALI/ARDS (e.g., [240-248]). Persistent elevations of proinflammatory cytokines in BAL and plasma from patients with ALI/ARDS have also been shown to be predictive of poor clinical outcome [246-248]. This provides a rationale for therapies with anti-inflammatory agents or antioxidants in ALI/ARDS to complement interventions targeting ventilation/perfusion abnormalities described in the preceding section. 
Medicinal chemical agents targeting inflammation and oxidant pathology that have been studied in humans or animals with ALI/ARDS or sepsis are summarized in Table 4. Agents targeting specific inflammatory mediators or pathways include antibodies or soluble receptors for tumor necrosis factor (TNF)- $\alpha$ [249-253], IL-8 [254-256], and CD40 ligand (CD40L) [257,258]. Also studied have been receptor antagonists for IL-1 (IL-1Ra) [259-262], and antibodies against bacterial products such as endotoxin [263,264]. In addition, pentoxifylline has been found to have anti-inflammatory properties of potential utility in ALI/ARDS and sepsis [265-276], and oxidant injury has been targeted by agents like N-acetylcysteine (NAC) [277-285] and recombinant superoxide dismutase (SOD) [286-288]. Corticosteroids, which have broad anti-inflammatory activity, have been found to be ineffective and even potentially harmful in early exudative ALI/ARDS (for review see [289]). However, corticosteroids are discussed later for potential use in the fibroproliferative phase of lung injury.

\subsection{Anti-TNFa Antibodies, Receptor Antagonists, or Soluble Receptors}

TNF $\alpha$ is an important early pro-inflammatory mediator of acute pulmonary injury ([290292] for review). TNF $\alpha$ not only has direct cellular actions, but also induces other proinflammatory mediators like IL- $1 \beta$ and promotes the recruitment of activated neutrophils into the lungs. The correlation between levels of TNFa and the development of ALI/ARDS is highest when this cytokine is measured in edema or BAL fluid [240-242]. Anti-TNF $\alpha$ or $\mathrm{TNF} \alpha$ receptor blockade has been shown to reduce the severity of lung injury in several animal models [250,293-295]. Acute benefits have also been reported following the delivery of monoclonal anti-TNF $\alpha$ antibodies to patients with ARDS or sepsis, but long term outcomes including survival were not significantly improved $[249,251,252]$. However, since TNF $\alpha$ is crucial in the innate antibacterial response, a failure to be more selective in choosing patient groups to receive anti-TNF therapy may have contributed to this lack of long term benefit. Antibodies to TNF $\alpha$ and receptor blockade strategies including the use of soluble TNF receptors (e.g., Enbrel) appear to be well tolerated in patients, and agents antagonizing the activity of this cytokine are potential candidates for use in combination therapies for ALI/ ARDS.

\subsection{Anti-IL-8 Antibodies}

IL-8 is a potent chemoattractant cytokine (chemokine) for neutrophils, and has been studied as a marker for ALI/ARDS in high-risk patients [246,296-299]. IL-8 has also been shown to affect neutrophil apoptosis [300]. IL-8 levels are markedly elevated in pulmonary edema from patients with ARDS compared to lung fluid from healthy volunteers or patients with hydrostatic edema [246,296-298]. High IL-8 levels in lavage also correlate with increased mortality in patients with ALI/ARDS [246], and with a high risk for development of ARDS [297]. IL-8 levels in lavage do not correlate with the persistence of ARDS [299], suggesting more importance in the pathogenesis of acute disease. Early treatment with anti-IL-8 antibodies has been found to reduce lung injury and mortality in animal models of acid aspiration [254] and endotoxemia [255,256]. Antibodies to IL-8 have not yet been studied in single-agent or combination therapies in patients with ALI/ARDS.

\subsection{Anti-CD40L}

$\mathrm{CD} 40$ is a $50 \mathrm{kD}$ receptor that was once thought to be expressed only on bone marrow-derived cells, but is now known also to be present on pulmonary fibroblasts [257,301-303]. Fibroblast CD40 serves as an activation structure for the synthesis of pro-inflammatory cytokines through interactions with CD40 ligand (CD40L), which is found on T lymphocytes and mast cells. A monoclonal anti-CD40L antibody termed MR1, which disrupts the CD40-CD40L interaction, has been shown to reduce the severity of hyperoxic lung injury and radiation-induced lung injury in mice $[257,258]$. In radiation-induced lung injury, treatment with MR1 not only 
improved acute injury, but also reduced fibrosis [258]. Caution is suggested, however, by a subsequent study in CD40- and CD40L-deficient mice $(-/-)$, which failed to show improvements in oxygen-induced injury in the absence of CD40 activity [304]. Anti-CD40L reagents for humans are in the testing phase by several pharmaceutical firms for diseases such as idiopathic thrombocytopenic purpura, but they have not been studied clinically in single or multi-agent therapies for ALI/ARDS.

\subsection{Granulocyte-Macrophage Colony-Stimulating Factor (GM-CSF)}

GM-CSF is a novel agent that has been shown to play an important role in the development and homeostasis of alveolar macrophages. Recombinant GM-CSF has been shown to reduce lung injury and mortality in an animal model of neutropenic Candida sepsis [305], and a small randomized phase-II study of GM-CSF in patients with severe sepsis and ALI/ARDS showed an improvement in oxygenation over a period of 5 days [306]. A randomized controlled trial of a 14 day course of GM-CSF in ALI/ARDS is currently ongoing at the University of Michigan.

\subsection{Pentoxifylline}

The xanthine derivative pentoxifylline is a phosphodiesterase inhibitor with multiple physiological effects. Pentoxifylline has direct vasodilatory activity, and it also affects erythrocyte deformability [307,308]. However, its major beneficial actions in ALI/ARDS appear to relate to its ability to raise cyclic adenosine monophosphate (cAMP) levels [309311], inhibit free radical formation [265], and antagonize the production and actions of TNF $\alpha$ $[272,275,276,312,313]$. Pentoxifylline has been shown to mitigate ALI/ARDS in multiple animal models [265-271], as well as to reduce levels of TNF $\alpha$ and improve cardiopulmonary function in patients with sepsis [272-276]. However, pentoxifylline and related phosphodiesterase inhibitors have not yet been evaluated in large clinical trials in adults with ALI/ARDS.

\subsection{Thromboxane Synthase and 5-Lipoxygenase Inhibitors}

Various cells of the pulmonary circulation including endothelial cells release metabolites of arachidonic acid including the thromboxanes and leukotrienes. While thromboxanes cause platelet aggregation and vasoconstriction, leukotrienes cause broncho-constriction and act as powerful neutrophilic chemokines. Ketoconazole, a synthetic antifungal inhibits thromboxane and leukotriene synthesis, and thus may be of benefit in antagonizing this aspect of the inflammatory response in ALI/ARDS. Three clinical trials have shown that Ketoconazole when given prophylactically prevented ARDS in high-risk patients, and in one of these studies there was an observed mortality benefit in those receiving prophylaxis [314-316]. A large ARDS network study using $400 \mathrm{mg} /$ day Ketoconazole early in the course of ALI/ARDS was unable to show any difference in gas exchange, ventilator-free days, or mortality [317] However, the use of Ketoconazole in the prophylactic mode in high risk patients was not addressed in this latter study and considering a lower dose of Ketoconazole was used, this strategy still remains of potential therapeutic value based on the earlier clinical findings [314-316].

\subsection{N-Acetylcysteine (NAC)}

NAC is a precursor for glutathione (GSH), an antioxidant present in significant levels in the normal lung [318-320]. GSH has many biological actions, ranging from oxidant protection to participation in metabolic pathways such as those involving inflammatory mediator synthesis [321]. Lavage from patients with ALI/ARDS is deficient in GSH [244], and GSH levels are also below average in some pulmonary fibrotic disorders [322]. Increased intracellular levels of GSH reduce production of pro-inflammatory cytokines like TNF $\alpha$ and IL-1 [318,323]. In addition to promoting GSH production, NAC also has direct antioxidant properties because of 
its thiol group, and it can scavenge reactive oxidants including hydrogen peroxide, superoxide anion, and hypochlorus acid [323]. Animal studies indicate that NAC has significant protective effects against acute pulmonary injury from hyperoxia, endotoxin, or GSH synthesis inhibition [277-282]. NAC has been reported to improve respiratory function but not survival in adults with ALI/ARDS [283-285]. A double-blind, placebo-controlled study in 48 patients at five centers found that treatment with NAC or procysteine (2-oxo-4-thiazolidinecarboxylic acid, a cysteine analog and GSH precursor) increased cardiac index and decreased the number of days of ALI without improving mortality [285]. However, an ARDS Network trial of procysteine for patients with ARDS was terminated early due to lack of evidence of efficacy [285]. No adverse side effects have been reported from the use of NAC in patients with ALI/ARDS, consistent with the broad experience with this drug as an antidote for acetaminophen overdose. No studies to date have investigated the utility of NAC in combination therapies for ALI/ ARDS.

\subsection{Superoxide Dismutase (SOD) and Related Antioxidants}

SOD acts to catalyze the conversion of superoxide anion to hydrogen peroxide [320,324, 325], which is subsequently converted to water by GSH peroxidase or by catalase, a tetrameric, heme-containing enzyme [320,325]. SOD exists primarily in three physiological forms: cytoplasmic SOD (Cu,Zn-containing), mitochondrial SOD (Mn-containing), and extracellular SOD (Cu-containing) [324,325]. The levels of extracellular SOD are relatively high in lung and brain tissue [326,327], and it has been speculated that this form of SOD may have a particular role in pulmonary anti-oxidant defense [287]. Cellular forms of SODs (cytoplasmic, mitochondrial) also have important anti-oxidant activity. In therapeutic applications involving the delivery of exogenous SODs to decrease superoxide anion, it is important to take into account that resulting increases in $\mathrm{H}_{2} \mathrm{O}_{2}$ could lead to hydroxyl radical production if the physiologic ability to scavenge $\mathrm{H}_{2} \mathrm{O}_{2}$ is exceeded. Animal studies show that hydroxyl radical production can cause oxidant-mediated lung injury as severe as that from superoxide [328]. A number of studies have shown that exogenously administered anti-oxidant enzymes, particularly when encapsulated in lipid vesicles (liposomes) or conjugated to polyethylene glycol to prolong biological half-life and aid delivery to cells, can protect against oxidant damage and mitigate the severity of acute pulmonary injury [288,329-334]. The majority of these studies have involved delivery of $\mathrm{Cu}, \mathrm{Zn}$-SOD by tracheal instillation $[288,329,330$, 332-334], although intraperitoneal injection has also been used [331]. Recombinant forms of several human SODs are available for clinical use in ALI/ARDS [286-288]. These enzymes have not been studied in any detail in combination therapies, although instillation of SODs with exogenous surfactant has been suggested as one approach to treating acute pulmonary injury [286,335]. In addition to SODs, several other anti-oxidant agents have been studied in therapeutic applications for lung injury. This includes EUK-8, a synthetic low molecular weight compound with SOD-like and catalase-like activity [336,337].

\subsection{Immunonutrition}

Providing early and appropriate enteral nutrition to critically-ill patients is a clinical standard of care. Enteral nutrition containing eicosapentaenoic acid (EPA, fish oil), gamma-linolenic acid (GLA, borage oil), and anti-oxidants including Vitamins E and C (termed collectively as immuno-nutrition), has been shown to reduce the days of mechanical ventilation, intensive care requirements, and the incidence of extra-pulmonary organ failure in patients with ARDS [338]. In retrospective subgroup analysis from this trial, it was also shown that levels of IL-8 and leukotriene B4 in bronchoalveolar lavage fluid were reduced in patients given enteral nutrition enriched in EPA and GLA [339]. A meta analysis of twelve randomized clinical trials using enteral formulas containing antioxidants suggested a reduction in infectious complications, but no observed differences in mortality [340]. Further studies are needed to 
define more fully the specific benefits of anti-oxidants in enteral nutrition regimens for patients with ALI/ARDS.

\section{AGENTS TARGETING THE FIBROPROLIFERATIVE PHASE OF ALI/ARDS}

As discussed earlier (Section III, Table 2), interventions in the fibroproliferative phase of ALI/ ARDS must primarily address pathophysiological elements of remodeling, repair and fibrosis as opposed to acute issues of cardio-respiratory instability. Current understanding of fibroproliferative lung injury suggests that therapeutic agents need to enhance repair (e.g., angiogenesis and alveolar secondary crest formation) while inhibiting fibroblast proliferation, differentiation, and interstitial matrix deposition. The necessity to include epithelial rescue in therapies for ALI/ARDS has been emphasized [63], although the detailed roles of epithelial cells in chronic lung injury remain unclear. Epithelial cell inflammatory mediator production and surfactant metabolism must also be normalized. Selected agents targeting various aspects of pathophysiology in fibroproliferative ALI/ARDS are summarized in Table 5 and are discussed below.

\subsection{Agents to Reduce Persistent Inflammation in Fibroproliferative ALI/ARDS}

Persistent inflammation is characteristic of patients that progress to fibroproliferative or fibrotic lung disease following acute exudative ALI/ARDS. Some anti-inflammatory agents already discussed for the acute phase of lung injury may have utility against these aspects of fibroproliferative phase pathology in combination therapies. In addition, anti-inflammatory agents like corticosteroids appear to have increased benefits in fibroproliferative lung injury compared to acute injury. During the early exudative phase of ALI/ARDS, corticosteroids are ineffective and even potentially harmful in patients [341,342]. In contrast, multiple studies have found improved outcomes for patients with established, fibroproliferative ARDS treated with corticosteroids over a prolonged course [343-350]. For example, Meduri et al. [349, 350] reported that patients who had no improvement in lung injury scores and were deemed non-responders at day 7 of acute ALI/ARDS had reduced inflammation and significant improvements in lung injury and survival following prolonged corticosteroid treatment. More recently the ARDS network published less positive results for methylprednisolone in patients with ARDS of at least 7 days duration [351]. Results showed that although there was a reduction in ventilator-free days, there was a significant increase in mortality at 60 and 180 days [351]. The use of inhaled rather than systemic corticosteroids in the fibroproliferative phase of ARDS to attempt to minimize drug-associated toxicity is currently under investigation.

A variety of anti-inflammatory compounds other than corticosteroids may be useful in treating fibroproliferative lung injury, but little direct clinical testing of potential agents has been done to date. A case series of 5 premature infants with BPD, a chronic fibrotic lung disease due to premature birth, has suggested reduced oxygen requirements, improved compliance, and reduced airway resistance following treatment with nebulized pentoxifylline [352]. This uncontrolled clinical experience supports further research on phosphodiesterase inhibitors as potentially relevant for fibroproliferative ALI/ARDS.

\subsection{Agents to Re-Establish Matrix Deposition and Turnover in Fibroproliferativ}

ALI/ARDS-Myofibroblast and endothelial cell invasion of the provisional matrix formed by protein exudation and coagulation initiates a "fibrosing alveolitis" and fibrotic interstitial foci in injured lungs. Fibroblast activation, migration, proliferation and collagen production in lung injury is augmented by cytokines and growth factors including transforming growth factor beta (TGF $\beta$ ), platelet derived growth factor (PDGF), and TNFa. Agents under consideration to inhibit fibroblast-dependent fibrosis include antagonists to PDGF, inhibitors of TGF $\beta$ mediated matrix protein production, and agents to promote fibroblast apoptosis including 
PDGF tyrosine kinase inhibitors such as relaxin and lovastatin [353-355]. Other biologics like anti-CD44 antibody, which reacts with the cell-surface matrix receptor located on invading fibroblasts, may also promote apoptosis and resolution of fibroproliferation [356]. Additional agents that could potentially reduce fibroblast activity and restrict matrix formation include cytotoxic drugs like cyclophosphamide [357] or azothioprine [358], as well as interferon gamma and beta, colchicine, pirfenidone and D-penicillamine ([59,64], for review). However, despite the contributions of fibroblasts to chronic lung injury, it is not clear that inhibition of these cells will be effective in mitigating or reversing disease. Moreover, some degree of fibroblast activity and matrix deposition likely protects pulmonary architecture and enhances remodeling and repair, so that the use of cytotoxic agents targeting these cells has potential risks as well as benefits.

Two groups of enzymes that appear to be important in fibroproliferative lung injury are the matrix metalloproteinases (MMPs) and their negative regulators, the tissue inhibitors of metalloproteinases (TIMPs). These enzymes are thought to participate in establishing a balanced distribution of matrix to support normal pulmonary structure and function, as opposed to the relatively disorganized interstitial network that constitutes scarring or fibrosis in injured lungs. An imbalance between the activities of MMPs and TIMPs in injured lungs may thus promote abnormal composition, distribution or organization of matrix proteins and contribute to fibrosis. MMPs including collagenases and gelatinases have been found to be reduced in lavage from patients with ARDS and interstitial pulmonary fibrosis, while TIMPs were increased especially in fibrotic loci [359]. On the other hand, MMP activity has been found to be increased in mice with bleomycin-induced fibrosis [360]. Although MMPs and TIMPs are clearly relevant for fibroproliferative lung injury, a better basic research understanding of the regulation and balance of these enzymes in healthy and injured lungs is needed to allow the development of pharmacologic agents directed at related aspects of lung injury pathology in ALI/ARDS.

\subsection{Agents to Improve Perfusion or Hypertension in Fibroproliferative ALI/ARDS}

Pulmonary hypertension induced by arterial muscularization and fibrous narrowing or replacement of the microcirculation frequently contributes to the morbidity and mortality of chronic lung injury. Concomitant with these airway changes, platelet aggregation and fibrinrich microthrombus formation within the vasculature cause increased pulmonary vascular resistance and pulmonary hypertension. Hypoxic pulmonary vasoconstriction and endogenous vasoconstrictors also contribute to the development of pulmonary hypertension in patients with ALI/ARDS [361]. A number of agents to improve pulmonary blood flow are under study in basic research, including endothelin (ET-1) receptor antagonists, prostaglandin derivatives, and anti-coagulants that could potentially be combined with (or replace) the conventional use of oxygen and vasodilating agents to reduce pulmonary vascular resistance in fibroproliferative ALI/ARDS (e.g., [362-364]). Studies using the endothelin receptor antagonist Tezosentan in a sheep model of endotoxin induced lung injury have demonstrated that treated animals exhibit reduced pulmonary edema, pulmonary hypertension and hypoxemia [364]. However, therapies with these agents are still in the developmental stage and have not been tested clinically in ALI/ARDS.

\section{SUMMARY}

Developing optimal pharmacotherapy for the severe clinical syndromes of ALI/ARDS ultimately depends on a detailed understanding of the pathophysiology of acute pulmonary injury, coupled with discovery-based medicinal chemical research and focused drug activity testing in cells, animals, and patients. To aid in future basic and applied medicinal chemistry research on new agents, this paper has reviewed current pharmacotherapy for ALI/ARDS in 
the context of single-agent and combination therapies. Although current pharmacotherapy has not been highly successful in increasing survival in ALI/ARDS particularly in adults, improved mechanistic understanding of the pathogenic mechanisms involved in the individual insults responsible for acute and chronic lung injury have identified multiple biochemical and biological targets for future drug discovery and development. A number of agents including GM-CSF, activated protein C, active exogenous surfactant, and several vasoactive, antiinflammatory, and anti-oxidant drugs are presently under clinical investigation as described in preceding sections. A variety of additional agents directed at specific biological aspects of acute and chronic lung injury are also being examined in continuing cell, molecular and animal research. The development of improved pharmacotherapy for ALI/ARDS should also benefit from the now-recognized importance of focusing many pulmonary-acting therapies on direct as opposed to indirect forms of these clinical syndromes.

In addition to single-agent treatments for ALI/ARDS, the possible benefits of combination therapies that simultaneously attack multiple aspects of pathophysiology are also becoming more widely appreciated. Individual pharmacological agents address only limited aspects of the complex, multifaceted pathophysiology of lung injury. The efficacy of an agent in mitigating its targeted element of disease can thus be obscured in terms of overall survival by other remaining elements of disease in critically-ill patients with ALI/ARDS. Several agents currently tested only as individuals may prove to have greater efficacy in improving survival or other long term outcomes when incorporated into combination therapies based on mechanistic understanding. Such therapies could potentially include combining multiple pharmacological agents having mechanistic synergy or additivity, or combining a pharmacological treatment with specific non-drug interventions such as different modes or strategies of mechanical ventilation or fluid balance.

Developing optimal medicinal chemical agents and combination therapy strategies for ALI/ ARDS requires continuing complementary basic science and clinical research. Further chemistry-based laboratory research focusing on the discovery of new agents is essential, as are detailed cell and animal model studies testing putative agents for their activity alone and in mechanistically-complementary combinations. Direct clinical testing of new promising agents is of course crucial, although clinical trials in ALI/ARDS are complicated by the heterogeneity of patient populations and the multiple etiologies and broad pathology of lung injury. A rational approach to drug discovery and development that integrates findings on mechanistic activity and agent efficacy in basic research to facilitate the design and analysis of focused clinical trials will be necessary for defining optimal pharmacotherapies for ALI/ ARDS-related lung injury in patients of all ages.

\section{Acknowledgements}

This study was supported in part by grants GM073826 (KR), HL56176 (RN, PC), HL077415 (GP), and HL48889 (PK, BD) from the National Institutes of Health.

\section{References}

1. Bernard GR, Artigas A, Brigham KL, Carlet J, Falke K, Hudson L, Lamy M, Legall JR, Morris A, Spragg R. Am J Respir Crit Care Med 1994;149:818-824. [PubMed: 7509706]

2. Esteban A, Fernandez-Segoviano P, Frutos-Vivar F, Aramburu JA, Najera L, Ferguson ND, Alia I, Gordo F, Rios F. Ann Intern Med 2004;141:440-445. [PubMed: 15381517]

3. Murray JF, Matthay MA, Luce JM, Flick MR. Am Rev Respir Dis 1988;138:720-723. [PubMed: 3202424]

4. American College of Chest Physicians Society of Critical Care Medicine Consensus Conference Committee. Crit Care Med 1992;20:864-874. [PubMed: 1597042]

5. Pollack MM, Patel KM, Ruttimann UE. Crit Care Med 1996;24:743-752. [PubMed: 8706448] 
6. Slater A, Shann F. ANZICS Paediatric Study Group. Pediatr Crit Care Med 2004;5:447-454. [PubMed: 15329160]

7. Shann F, Pearson G, Slater A, Wilkinson K. Intensive Care Med 1997;23:201-207. [PubMed: 9069007]

8. Trachsel D, McCrindle BW, Nakagawa S, Bohn D. Am J Respir Crit Care Med 2005;172:206-211. [PubMed: 15817802]

9. Ferguson ND, Davis AM, Slutsky AS, Stewart TE. J Crit Care 2005;20:147-154. [PubMed: 16139155]

10. Ferguson ND, Frutos-Vivar F, Esteban A, Fernandez-Segoviano P, Aramburu JA, Najera L, Stewart TE. Crit Care Med 2005;33:2228-2234. [PubMed: 16215375]

11. Hudson LD, Milberg JA, Anardi D, Maunder RJ. Am J Respir Crit Care Med 1995;151:293-301. [PubMed: 7842182]

12. Krafft P, Fridrich P, Pernerstorfer T, Fitzgerald RD, Koc D, Schneider B, Hammerle AF, Steltzer H. Intensive Care Med 1996;22:519-529. [PubMed: 8814466]

13. Doyle RL, Szaflarski N, Modin GW, Wiener-Kronish JP, Matthay MA. Am J Respir Crit Care Med 1995;152:1818-1824. [PubMed: 8520742]

14. Ware LB, Matthay MA. N Engl J Med 2000;342:1334-1348. [PubMed: 10793167]

15. Rubenfeld GD. Crit Care Med 2003;31:S276-284. [PubMed: 12682453]

16. Rubenfeld GD, Caldwell E, Peabody E, Weaver J, Martin DP, Neff M, Stern EJ, Hudson LD. N Engl J Med 2005;353:1685-1693. [PubMed: 16236739]

17. Goss CH, Brower RG, Hudson LD, Rubenfeld GD. Crit Care Med 2003;31:1607-1611. [PubMed: 12794394]

18. Baue AE, Durham R, Faist E. Shock 1998;10:79-89. [PubMed: 9721973]

19. Karima R, Matsumoto S, Higashi H, Matsushima K. Mol Med Today 1999;5:123-132. [PubMed: 10203736]

20. Willson DF, Thomas NJ, Markovitz BP, DiCarlo JV, Pon S, Jacobs BR, Jefferson LS, Conaway MR, Egan EA. JAMA 2005;293:470-476. [PubMed: 15671432]

21. Spragg RG, Lewis JF, Wurst W, Hafner D, Baughman RP, Wewers MD, Marsh JJ. Am J Respir Crit Care Med 2003;167:1562-1566. [PubMed: 12649125]

22. Bersten AD, Edibam C, Hunt T, Moran J. Am J Respir Crit Care Med 2002;165:443-448. [PubMed: 11850334]

23. Pfenninger J, Gerber A, Tschappeler H, Zimmerman A. J Pediatr 1982;101:352-357. [PubMed: 7050328]

24. Bindl L, Dresbach K, Lentze M. Crit Care Med 2005;33:209-212. [PubMed: 15644671]

25. Manzano F, Yuste E, Colmenero M, Garcia-Horcajadas A, Rivera R, Fernandez-Mondejar E. Granada Respiratory Failure Study Group. J Crit Care 2005;20:274-280. [PubMed: 16253798]

26. Flori HR, Glidden DV, Rutherford GW, Matthay MA. Am J Respir Crit Care Med 2005;171:9951001. [PubMed: 15618461]

27. The Paediatric Study Group of the Australian and New Zealand Intensive Care Society (ANZICS). Pediatr Crit Care Med 2007;8:317-323. [PubMed: 17545931]

28. DeBruin W, Notterman DA, Magid M, Godwin T, Johnston S. Crit Care Med 1992;20:1223-1234. [PubMed: 1521437]

29. Timmons OD, Havens PL, Fackler JC. (Pediatric Critical Care Study Group and the Extracorporeal Life Support Organization). Chest 1995;108:789-797. [PubMed: 7656635]

30. Dahlem P, van Aalderen WMC, Hamaker ME, Dijkgraaf MG, Bos AP. Eur Respir J 2003;22:980983. [PubMed: 14680089]

31. Curley MA, Hibberd PL, Fineman LD, Wypij D, Shih MC, Thompson JE, Grant MJ, Barr FE, Cvijanovich NZ, Sorce L, Luckett PM, Matthay MA, Arnold JH. JAMA 2005;294(2):229-237. [PubMed: 16014597]

32. The Acute Respiratory Distress Syndrome Network. N Engl J Med 2000;342:1301-1308. [PubMed: 10793162]

33. Willson DF, Thomas NJ, Markovitz BP, Bauman LA, DiCarlo JV, Pon S, Jacobs BR, Jefferson LS, Conaway MR, Egan EA. JAMA 2005;293:470-476. [PubMed: 15671432] 
34. Pryhuber, GS.; D’Angio, CT.; Finkelstein, JN.; Notter, RH. Lung injury: Mechanisms, pathophysiology, and therapy. Notter, RH.; Finkelstein, JN.; Holm, BA., editors. Taylor Francis Group, Inc; Boca Raton: 2005. p. 779-838.

35. Lanzenberger-Schragl E, Donner A, Kashanipour A, Zimpfer M. Acta Anaesthesiol Scand Suppl 1996;109:157-161. [PubMed: 8901991]

36. Fort P, Farmer C, Westerman J, Johannigman J, Beninati W, Dolan S, Derdak S. Crit Care Med 1997;25:937-947. [PubMed: 9201044]

37. Mammel MC. Crit Care Med 2001;29:1293. [PubMed: 11395630]

38. Bigatello LM, Patroniti N, Sangalli F. Curr Opin Crit Care 2001;7:34-40. [PubMed: 11373509]

39. Brower RG, Fessler HE. Clin Chest Med 2000;21:491-510. [PubMed: 11019722]

40. Medoff BD, Harris RS, Kesselman H, Venegas J, Amato MB, Hess D. Crit Care Med 2000;28:12101216. [PubMed: 10809308]

41. Papadakos PJ, Lachmann B. Mt Sinai J Med 2002;69:73-77. [PubMed: 11832975]

42. Eisner MD, Thompson T, Hudson LD, Luce JM, Hayden D, Schoenfeld D, Matthay MA. Am J Respir Crit Care Med 2001;164:231-236. [PubMed: 11463593]

43. Hess DR, Bigatello LM. Respir Care 2002;47:308-317. [PubMed: 11874609]discussion 317-318.

44. Mehta S, MacDonald R, Hallett DC, Lapinsky SE, Aubin M, Stewart TE. Crit Care Med 2003;31:383389. [PubMed: 12576940]

45. Steinbrook R. N Engl J Med 2003;348:1393-1401. [PubMed: 12672870]

46. Marraro GA. Pediatr Crit Care Med 2003;4:8-20. [PubMed: 12656536]

47. Johnson MD, Widdicombe JH, Allen L, Barbry P, Dobbs LG. Proc Natl Acad Sci USA 2002;99:19661971. [PubMed: 11842214]

48. Matthay MA, Wiener-Kronish JP. Am Rev Respir Dis 1990;142:1250-1257. [PubMed: 2252240]

49. Sartori C, Matthay MA, Scherrer U. Adv Exp Med Biol 2001;502:315-338. [PubMed: 11950147]

50. Matthay MA, Fukuda N, Frank J, Kallet R, Daniel B, Sakuma T. Clin Chest Med 2000;21:477-490. [PubMed: 11019721]

51. Knight, PR.; Rotta, AT. Lung injury: Mechanisms, pathophysiology, and therapy. Notter, RH.; Finkelstein, JN.; Holm, BA., editors. Taylor \& Francis Group; Boca Raton: 2005. p. 67-110.

52. Notter, RH. Lung surfactants: Basic science and clinical applications. Marcel Dekker, Inc; New York: 2000.

53. Wang, Z.; Holm, BA.; Matalon, S.; Notter, RH. Lung injury: Mechanisms, pathophysiology, and therapy. Notter, RH.; Finkelstein, JN.; Holm, BA., editors. Taylor Francis Group, Inc; Boca Raton: 2005. p. 297-352.

54. Lewis JF, Jobe AH. Am Rev Respir Dis 1993;147:218-233. [PubMed: 8420422]

55. Seeger W, Günther A, Walmrath HD, Grimminger F, Lasch HG. Clin Invest 1993;71:177-190.

56. Notter, RH.; Finkelstein, JN.; Holm, BA., editors. Lung injury: Mechanisms, pathophysiology and therapy. Taylor Francis Group, Inc; Boca Raton: 2005.

57. Nobauer-Huhmann IM, Eibenberger K, Schaefer-Prokop C, Steltzer H, Schlick W, Strasser K, Fridrich P, Herold CJ. Eur Radiol 2001;11:2436-2443. [PubMed: 11734936]

58. McHugh LG, Milberg JA, Whitcomb ME, Schoene RB, Maunder RJ, Hudson LD. Am J Respir Crit Care Med 1994;150:90-94. [PubMed: 8025779]

59. Selman M, King TE, Pardo A. Ann Intern Med 2001;134:136-151. [PubMed: 11177318]

60. Sime PJ, O’Reilly KMA. Clin Immunol 2001;99:308-319. [PubMed: 11358425]

61. Zhang K, Phan SH. Biol Signals 1996;5:232-239. [PubMed: 8891199]

62. Ward PA, Hunninghake GW. Am J Respir Crit Care Med 1998;157(Suppl):S123-S129. [PubMed: 9563771]

63. Berthiaume Y, Lesur O, Dagenais A. Thorax 1999;54:150-160. [PubMed: 10325922]

64. Lasky JA, Ortiz LA. Am J Med Sci 2001;322:213-221. [PubMed: 11678519]

65. Kaisers U, Busch T, Deja M, Donaubauer B, Falke KJ. Crit Care Med 2003;31(Suppl):S337-S342. [PubMed: 12682462]

66. Ignarro LJ, Buga GM, Wood KS, Byrns RE, Chaudhuri G. Proc Natl Acad Sci USA 1987;84:92659269. [PubMed: 2827174] 
67. Palmer R, Ferrige A, Moncada S. Nature 1987;327:524-526. [PubMed: 3495737]

68. Palmer R, Ashton D, Moncada S. Nature 1988;333:664-666. [PubMed: 3131684]

69. Kinsella JP, Truog WE, Walsh WF, Goldberg RN, Bancalari E, Clark RH, Mayock DE, Redding GJ, deLemos RA, Sardesai S, McCurnin DC, Yoder BA, Moreland SG, Cutter GR, Abamn SH. J Pediatr 1997;131:55-62. [PubMed: 9255192]

70. Nelin LD, Hoffman GM. Pediatr Clin North Am 1998;45:531-548. [PubMed: 9653435]

71. Troncy E, Francoeur M, Blaise G. Can J Anaesth 1997;44:973-988. [PubMed: 9305562]

72. Roberts JD, Fineman JR, Morin FC, Shaul PW, Rimar S, Schreiber MD, Polin RA, Zwass MS, Zayek MM, Gross I, Heymann MA, Zapol WM. N Engl J Med 1997;336:605-610. [PubMed: 9032045]

73. Goldman AP, Tasker RC, Haworth SG, Sigston PE, Macrae DJ. Pediatrics 1996;98:706-713. [PubMed: 8885950]

74. Hoffman GM, Ross RA, Day SE, Rice TB, Nelin LD. Crit Care Med 1997;25:352-359. [PubMed: 9034276]

75. Shah NS, Nakayama DK, Jacob TD, Nishio I, Imai T, Billiar TR, Exler R, Yousem SA, Motoyama EK, Peitzman AB. Arch Surg 1994;129:158-164. [PubMed: 8304827]

76. Putensen C, Rasanen J, Lopez F, Downs J. Chest 1994;106:1563-1569. [PubMed: 7956419]

77. Fratacci MD, Frostell C, Chen TY, Wain JC, Robinson DR, Zapol WM. Anesthesiology 1991;75:990_ 999. [PubMed: 1741521]

78. Berger JI, Gibson RL, Redding GJ, Standaert TA, Clarke WR, Truog WE. Am Rev Respir Dis 1993;147:1080-1086. [PubMed: 8484613]

79. Shah NS, Nakayama DK, Jacob TD, Nishio I, Imai T, Billiar TR, Exler R, Yousem SA, Motoyama EK, Peitzman AB. Crit Care Med 1997;25:153-158. [PubMed: 8989192]

80. Krause MF, Lienhart HG, Haberstroh J, Hoehn T, Shulte-Monting J, Leititis JU. Eur J Pediatr 1998;157:410-415. [PubMed: 9625340]

81. Rossaint R, Falke KJ, Lopez F, Slama K, Pison U, Zapol W. N Engl J Med 1993;328:399-405. [PubMed: 8357359]

82. Gerlach H, Rossaint R, Pappert D, Falke KJ. Eur J Clin Invest 1993;23:499-502. [PubMed: 8405003]

83. Young JD, Brampton WJ, Knighton JD, Finfer SR. Br J Anaesth 1994;73:499-502. [PubMed: 7999491]

84. Rossaint R, Gerlach H, Schmidt-Ruhnke H, Pappert D, Lewandowski K, Steudel W, Falke K. Chest 1995;107:1107-1115. [PubMed: 7705124]

85. Dellinger RP, Zimmerman JL, Taylor RW, Straube RC, Hauser DL, Criner GJ, Davis K, Hyers TM, Papadakos P. (INO in ARDS Study Group). Crit Care Med 1998;26:15-23. [PubMed: 9428538]

86. Troncy E, Collet JP, Shapiro S, Guimond JG, Blair L, Ducruet T, Francceur M, Charbonneau M, Blaise G. Am J Respir Crit Care Med 1998;157:1483-1488. [PubMed: 9603127]

87. Michael JR, Barton RG, Saffle JR, Mone M, Markewitz BA, Hillier K, Elstad MR, Campbell EJ, Troyer BE, Whatley RE, Liou TG, Samuelson WM, Carveth HJ, Hinson DM, Morris SE, Davis BL, Day RW. Am J Respir Crit Care Med 1998;157:1372-1380. [PubMed: 9603111]

88. Papazian L, Bregeon F, Gaillat F, Thirion X, Gainnier M, Gregoire R, Saux P, Gouin F, Jammes Y, Auffray JP. Am J Respir Crit Care Med 1998;157:580-585. [PubMed: 9476876]

89. Fierobe L, Brunet F, Dhainaut JF, Monchi M, Belghith M, Mira JP, Dallava-Santucci J, Dinh-Xuan A. Am J Respir Crit Care Med 1995;151:1414-1419. [PubMed: 7735594]

90. Neonatal Inhaled Nitric Oxide Study Group (NINOS). N Engl J Med 1997;336:597-604. [PubMed: 9036320]

91. Day RW, Guarin M, Lynch JM, Vernon DD, Mean JM. Crit Care Med 1996;24:215-221. [PubMed: 8605791]

92. Abman SH, Griebel JL, Parker DK, Schmidt JM, Swanton D, Kinsella JP. J Pediatr 1994;124:881888. [PubMed: 8201471]

93. Demirakca S, Dotsch J, Knotche C, Magsaam J, Reiter HL, Bauer J, Kuehl PG. Crit Care Med 1996;24:1913-1919. [PubMed: 8917045]

94. Okamoto K, Hamaguchi M, Kukita I, Kikuta K, Sato T. Chest 1998;114:827-833. [PubMed: 9743174] 
95. Goldman AP, Tasker RC, Hosiasson S, Henrichsen T, Macrae DJ. Chest 1997;112:752-758. [PubMed: 9315811]

96. Nakagawa TA, Morris A, Gomez RJ, Johnston SJ, Sharkey PT, Zaritsky AL. J Pediatr 1997;131:6369. [PubMed: 9255193]

97. Okamoto K, Kukita I, Hamaguchi M, Motoyama T, Muranaka H, Harada T. Artif Organs 2000;24:390-395. [PubMed: 10848682]

98. Borelli M, Lampati L, Vascotto E, Fumagalli R, Pesenti A. Crit Care Med 2000;28:2707-2712. [PubMed: 10966239]

99. Kinsella JP, Parker TA, Ivy DD, Abman SH. J Pediatr 2003;142:397-401. [PubMed: 12712057] 100. Sokol J, Jacobs SE, Bohn D. Cochrane Database Syst Rev 2003:CD002787. [PubMed: 12535438]

101. Zhu B, Strada SJ. Curr Top Med Chem 2007;7:437-454. [PubMed: 17305584]

102. Naeije R, Huez S. Expert Opin Pharmacother 2007;8:2247-2265. [PubMed: 17927481]

103. Uthayathas S, Karuppagounder SS, Thrash BM, Parameshwaran K, Suppiramaniam V, Dhanasekaran M. Pharmacol Rep 2007;59:150-163. [PubMed: 17556793]

104. Leibovitch L, Matok I, Paret G. Drugs 2007;67:57-73. [PubMed: 17209664]

105. Giacomini M, Borotto E, Bosotti L, Denkewitz T, Reali-Forster C, Carlucci P, Centanni S, Mantero A, Iapichino G. Anaesth Intensive Care 2007;35:91-93. [PubMed: 17323673]

106. Lobato EB, Beaver T, Muehlschlegel J, Kirby DS, Klodell C, Sidi A. Br J Anaesth 2006;96:317322. [PubMed: 16443640]

107. Zwissler B, Gregor K, Habler O, Kleen M, Merkel M, Haller M, Brigel J, Welte M, Peter K. Am J Respir Crit Care Med 1996;154:1671-1677. [PubMed: 8970353]

108. Walmrath D, Schneider T, Schermuly R, Olschewski H, Grimminger F, Seeger W. Am J Respir Crit Care Med 1996;153:991-996. [PubMed: 8630585]

109. Pappert D, Busch T, Gerlach H, Lewandowski K, Radermacher P, Rossaint R. Anesthesiology 1995;82:1507-1511. [PubMed: 7793662]

110. Putensen C, Hormann C, Kleinsasser A, Putensen-Himmer G. Am J Respir Crit Care Med 1998;157:1743-1747. [PubMed: 9620900]

111. Notter RH, Apostolakos M, Holm BA, Willson D, Wang Z, Finkelstein JN, Hyde RW. Perspect Neonatol 2000;1(4):4-20.

112. Papazian L, Roch A, Bregeon F, Thirion X, Gaillat F, Saux P, Fulachier V, Jammes Y, Auffray JP. Am J Respir Crit Care Med 1999;160:473-479. [PubMed: 10430716]

113. Jolliet P, Bulpa P, Ritz M, Ricou B, Lopez J, Chevrolet JC. Crit Care Med 1997;25:786-794. [PubMed: 9187597]

114. Gillart T, Bazin JE, Cosserant B, Guelon D, Aigouy L, Mansoor O, Schoeffler P. Can J Anesth 1998;45:402-409. [PubMed: 9598253]

115. Payen D, Muret J, Beloucif S, Gatecel C, Kermarrec N, Guinard N, Mateo J. Anesthesiology 1998;89:1158-1165.

116. Wysocki M, Roupie E, Langeron O, Liu N, Herman B, Lemaire F, Brochard L. Intensive Care Med 1994;20:254-259. [PubMed: 8046118]

117. Lu Q, Mourgeon E, Law-Koune J, Roche S, Vezinet C, Abdennour L, Vicaut E, Puybasset L, Diaby M, Coriat P, Rouby J. Anesthesiology 1995;83:929-943. [PubMed: 7486178]

118. Roch A, Papazian L, Bregeon F, Gainnier M, Michelet P, Thirion X, Saux P, Thomas P, Jammes Y, Auffray JP. Intensive Care Med 2001;27:1737-1743. [PubMed: 11810116]

119. Michard F, Wolff MA, Herman B, Wysocki M. Crit Care Med 2001;29:32-36. [PubMed: 11176154]

120. Doering EB, Hanson CW, Reily DJ, Marshall C, Marshall BE. Anesthesiology 1997;87:18-25. [PubMed: 9232130]

121. Troncy E, Blaise G. Anethesiology 1998;89:538-539.

122. Petty T, Reiss O, Paul G, Silvers G, Elkins N. Am Rev Respir Dis 1977;115:531-536. [PubMed: 576571]

123. Hallman M, Spragg R, Harrell JH, Moser KM, Gluck L. J Clin Invest 1982;70:673-683. [PubMed: 6896715] 
124. Seeger W, Pison U, Buchhorn R, Obestacke U, Joka T. Lung 1990;168(Suppl):891-902. [PubMed: 2117209]

125. Pison U, Seeger W, Buchhorn R, Joka T, Brand M, Obertacke U, Neuhof H, Schmit-Neuerberg K. Am Rev Respir Dis 1989;140:1033-1039. [PubMed: 2802366]

126. Gregory TJ, Longmore WJ, Moxley MA, Whitsett JA, Reed CR, Fowler AA, Hudson LD, Maunder RJ, Crim C, Hyers TM. J Clin Invest 1991;88:1976-1981. [PubMed: 1752956]

127. Veldhuizen R, McCaig L, Akino T, Lewis J. Am J Respir Crit Care Med 1995;152:1867-1871. [PubMed: 8520748]

128. Griese M. Eur Respir J 1999;13:1455-1476. [PubMed: 10445627]

129. Günther A, Siebert C, Schmidt R, Ziegle S, Grimminger F, Yabut M, Temmesfeld B, Walmrath D, Morr H, Seeger W. Am J Respir Crit Care Med 1996;153:176-184. [PubMed: 8542113]

130. Chess, P.; Finkelstein, JN.; Holm, BA.; Notter, RH. Lung injury: Mechanisms, pathophysiology, and therapy. Notter, RH.; Finkelstein, JN.; Holm, BA., editors. Taylor Francis Group, Inc; Boca Raton: 2005. p. 617-663.

131. Willson, DF.; Chess, PR.; Wang, Z.; Notter, RH. Pediatric Critical Care Medicine: Basic Science and Clinical Evidence. Wheeler, DA.; WH; Shanley, TA., editors. Springer-Verlag; London: 2007. p. 453-466.

132. Frerking I, Gunther A, Seeger W, Pison U. Intensive Care Med 2001;27:1699-1717. [PubMed: 11810113]

133. Kobayashi T, Ganzuka M, Taniguchi J, Nitta K, Murakami S. Acta Anaesthesiol Scand 1990;34:216-221. [PubMed: 2111628]

134. Zucker A, Holm BA, Wood LDH, Crawford G, Ridge K, Sznajder IA. J Appl Physiol 1992;73:679_ 686. [PubMed: 1399997]

135. Schlag G, Strohmaier W. Exp Lung Res 1993;19:397-405. [PubMed: 8319606]

136. Al-Mateen KB, Dailey K, Grimes MM, Gutcher GR. Pediatr Pulmonol 1994;17:75-80. [PubMed: 8165041]

137. Sun B, Curstedt T, Robertson B. Am J Respir Crit Care Med 1996;154:764-770. [PubMed: 8810617]

138. Cochrane CG, Revak SD, Merritt TA, Schraufstatter U, Hoch RC, Henderson C, Andersson S, Takamori H, Oades ZG. Pediatr Res 1998;44:705-715. [PubMed: 9803452]

139. Sun B, Curstedt T, Song GW, Robertson B. Biol Neonate 1993;63:96-104. [PubMed: 8448260]

140. Lachmann B, Hallman M, Bergman KC. Exp Lung Res 1987;12:163-180. [PubMed: 3569167]

141. Nieman G, Gatto L, Paskanik A, Yang B, Fluck R, Picone A. Crit Care Med 1996;24:1025-1033. [PubMed: 8681569]

142. Lutz C, Carney D, Finck C, Picone A, Gatto L, Paskanik A, Langenbeck E, Nieman G. Am J Respir Crit Care Med 1998;158:840-845. [PubMed: 9731014]

143. Lutz CJ, Picone A, Gatto LA, Paskanik A, Landas S, Nieman G. Crit Care Med 1998;26:1379-1389. [PubMed: 9710098]

144. Tashiro K, Li WZ, Yamada K, Matsumoto Y, Kobayashi T. Crit Care Med 1995;23:149-156. [PubMed: 8001366]

145. Eijking EP, van Daal GJ, Tenbrinck R, Luyenduijk A, Sluiters JF, Hannappel E, Lachmann B. Intensive Care Med 1990;17:475-478. [PubMed: 1797892]

146. Sherman MP, Campbell LA, Merritt TA, Long WA, Gunkel JH, Curstedt T, Robertson B. J Pediatr 1994;125:939-947. [PubMed: 7996369]

147. Berry D, Ikegami M, Jobe A. J Appl Physiol 1986;61:1741-1748. [PubMed: 3781984]

148. Matalon S, Holm BA, Notter RH. J Appl Physiol 1987;62:756-761. [PubMed: 3558235]

149. Loewen GM, Holm BA, Milanowski L, Wild LM, Notter RH, Matalon S. J Appl Physiol 1989;66:1987-1992.

150. Engstrom PC, Holm BA, Matalon S. J Appl Physiol 1989;67:688-693. [PubMed: 2793671]

151. Matalon S, Holm BA, Loewen GM, Baker RR, Notter RH. Exp Lung Res 1988;14:1021-1033. [PubMed: 3208725]

152. Novotny WE, Hudak BB, Matalon S, Holm BA. Am J Respir Crit Care Med 1995;151:1843-1847. [PubMed: 7767528] 
153. Lachmann, B.; Fujiwara, T.; Chida, S.; Morita, T.; Konishi, M.; Nakamura, K.; Maeta, H. Pulmonary Surfactant System. Cosmi, EV.; Scarpelli, EM., editors. Elsevier; Amsterdam: 1983. p. 221-235.

154. Kobayashi T, Kataoka H, Ueda T, Murakami S, Takada Y, Kobuko M. J Appl Physiol 1984;57:9951001. [PubMed: 6389455]

155. Berggren P, Lachmann B, Curstedt T, Grossmann G, Robertson B. Acta Anaesthesiol Scand 1986;30:321-328. [PubMed: 3090844]

156. Lewis JF, Goffin J, Yue P, McCaig LA, Bjarneson D, Veldhuizen RAW. J Appl Physiol 1996;80:1156-1164. [PubMed: 8926241]

157. Walther FJ, Hernandez-Juviel J, Bruni R, Waring A. Am J Respir Crit Care Med 1997;156:855861. [PubMed: 9310004]

158. Walther F, Hernandez-Juviel J, Bruni R, Waring AJ. Pediatr Res 1998;43:666-673. [PubMed: 9585014]

159. Harris JD, Jackson F, Moxley MA, Longmore WJ. J Appl Physiol 1989;66:1846-1851. [PubMed: 2732176]

160. Lewis JF, Ikegami M, Jobe AH. Am Rev Respir Dis 1992;145:19-23. [PubMed: 1731583]

161. Lewis J, Ikegami M, Higuchi R, Jobe A, Absolom D. J Appl Physiol 1991;71:1270-1276. [PubMed: 1757348]

162. van Daal GJ, So KL, Gommers D, Eijking EP, Fievez RB, Sprenger MJ, van Dam DW, Lachmann B. Anesth Analg 1991;72:589-595. [PubMed: 1850209]

163. van Daal GJ, Bos JAH, Eijking EP, Gommers D, Hannappel E, Lachmann B. Am Rev Respir Dis 1992;145:859-863. [PubMed: 1313214]

164. Khammash H, Perlman M, Wojtulewicz J, Dunn M. Pediatrics 1993;92:135-139. [PubMed: 8516059]

165. Findlay RD, Taeusch HW, Walther FJ. Pediatrics 1996;97:48-52. [PubMed: 8545223]

166. Auten RL, Notter RH, Kendig JW, Davis JM, Shapiro DL. Pediatrics 1991;87:101-107. [PubMed: 1984603]

167. Lotze A, Knight GR, Martin GR, Bulas DI, Hull WM, O’Donnell RM, Whitsett JA, Short BL. J Pediatr 1993;122:261-268. [PubMed: 8429445]

168. Lotze A, Mitchell BR, Bulas DI, Zola EM, Shalwitz RA, Gunkel JH. J Pediatr 1998;132:40-47. [PubMed: 9469998]

169. Luchetti M, Casiraghi G, Valsecchi R, Galassini E, Marraro G. Acta Anaesthesiol Scand 1998;42:805-810. [PubMed: 9698957]

170. Luchetti M, Ferrero F, Gallini C, Natale A, Pigna A, Tortorolo L, Marraro GA. Pediatr Crit Care Med 2002;3:261-268. [PubMed: 12780967]

171. Herting E, Moller O, Schiffman JH, Robertson B. Acta Paediatr 2002;91:1174-1178. [PubMed: 12463314]

172. Hermon MM, Golej J, Burda G, Boigner H, Stoll E, Vergesslich K, Strohmaier W, Pollak A, Trittenwein G. Shock 2002;17(4):247-251. [PubMed: 11954821]

173. Willson DF, Jiao JH, Bauman LA, Zaritsky A, Craft H, Dockery K, Conrad D, Dalton H. Crit Care Med 1996;24:1316-1322. [PubMed: 8706485]

174. Willson DF, Bauman LA, Zaritsky A, Dockery K, James RL, Stat M, Conrad D, Craft H, Novotny WE, Egan EA, Dalton H. Crit Care Med 1999;27:188-195. [PubMed: 9934915]

175. Walmrath D, Grimminger F, Pappert D, Knothe C, Obertacke U, Benzing A, Gunther A, Schmehl T, Leuchte H, Seeger W. Eur Respir J 2002;19:805-810. [PubMed: 12030717]

176. Walmrath D, Gunther A, Ghofrani HA, Schermuly R, Schnedier T, Grimminger F, Seeger W. Am J Respir Crit Care Med 1996;154:57-62. [PubMed: 8680699]

177. Gunther A, Schmidt R, Harodt J, Schmehl T, Walmrath D, Ruppert C, Grimminger F, Seeger W. Eur Respir J 2002;19(5):797-804. [PubMed: 12030716]

178. Spragg R. Biol Neonate 1998;74(Suppl):15-20. [PubMed: 9730587]

179. Spragg R, Gilliard N, Richman P, Smith R, Hite R, Pappert D, Robertson B, Curstedt T, Strayer D. Chest 1994;105:195-202. [PubMed: 8031347] 
180. Anzueto A, Baughman RP, Guntupalli KK, Weg JG, Wiedemann HP, Raventos AA, Lemaire F, Long W, Zaccardelli DS, Pattishall EN. (Exosurf ARDS Sepsis Study Group). N Engl J Med 1996;334:1417-1421. [PubMed: 8618579]

181. Seeger W, Grube C, Günther A, Schmidt R. Eur Respir J 1993;6:971-977. [PubMed: 8370446]

182. Hall SB, Venkitaraman AR, Whitsett JA, Holm BA, Notter RH. Am Rev Respir Dis 1992;145:2430. [PubMed: 1731593]

183. Hudak ML, Farrell EE, Rosenberg AA, Jung AL, Auten RL, Durand DJ, Horgan MJ, Buckwald S, Belcastro MR, Donohue PK, Carrion V, Maniscalco WM, Balsan MJ, Torres BA, Miller RR, Jansen RD, Graeber JE, Laskay KM, Matteson EJ, Egan EA, Brody AS, Martin DJ, Riddlesberger MM, Montogomery P. (21 Center group). J Pediatr 1996;128:396-406. [PubMed: 8774514]

184. Bloom BT, Kattwinkel J, Hall RT, Delmore PM, Egan EA, Trout JR, Malloy MH, Brown DR, Holzman IR, Coghill CH, Carlo WA, Pramanik AK, McCaffree MA, Toubas PL, Laudert S, Gratny LL, Weatherstone KB, Seguin JH, Willett LD, Gutcher GR, Mueller DH, Topper WH. (13 Center group). Pediatrics 1997;100:31-38. [PubMed: 9200357]

185. Hudak ML, Martin DJ, Egan EA, Matteson EJ, Cummings J, Jung AL, Kimberlin LV, Auten RL, Rosenberg AA, Asselin JM, Belcastro MR, Donahue PK, Hamm CR, Jansen RD, Brody AS, Riddlesberger MM, Montgomery P. (10 Center group). Pediatrics 1997;100:39-50. [PubMed: 9200358]

186. Horbar JD, Wright LL, Soll RF, Wright EC, Fanaroff AA, Korones SB, Shankaran S, Oh W, Fletcher BD, Bauer CR. (NIH NICHHD Neonatal Research Network). J Pediatr 1993;123:757-766. [PubMed: 8229487]

187. Vermont-Oxford Neonatal Network. Pediatrics 1996;97:1-6. [PubMed: 8545199]

188. Rollins M, Jenkins J, Tubman R, Corkey C, Wilson D. J Perinat Med 1993;21:341-347. [PubMed: 8126629]

189. Sehgal SS, Ewing CK, Richards T, Taeusch HW. J Natl Med Assoc 1994;86:46-52. [PubMed: 8151722]

190. Choukroun ML, Llanas B, Apere H, Fayon M, Galperine RI, Guenard H, Demarquez JL. Pediatr Pulmonol 1994;18:273-298. [PubMed: 7898964]

191. Gregory TJ, Steinberg KP, Spragg R, Gadek JE, Hyers TM, Longmere WJ, Moxley MA, GuangZuan CAI, Hite RD, Smith RM, Hudson LD, Crim C, Newton P, Mitchell BR, Gold AJ. Am J Respir Crit Care Med 1997;155:109-131. [PubMed: 9001298]

192. Notter RH, Wang Z, Egan EA, Holm BA. Chem Phys Lipids 2002;114:21-34. [PubMed: 11841823]

193. Curstedt T, Jornvall H, Robertson B, Bergman T, Berggren P. Eur J Biochem 1987;168:255-262. [PubMed: 3665923]

194. Oosterlaken-Dijksterhuis MA, Haagsman HP, van Golde LM, Demel RA. Biochemistry (Mosc) 1991;30:10965-10971.

195. Oosterlaken-Dijksterhuis MA, Haagsman HP, van Golde LM, Demel RA. Biochemistry (Mosc) 1991;30:8276-8281.

196. Oosterlaken-Dijksterhuis MA, van Eijk M, van Golde LMG, Haagsman HP. Biochim Biophys Acta 1992;1110:45-50. [PubMed: 1390835]

197. Revak SD, Merritt TA, Degryse E, Stefani L, Courtney M, Hallman M, Cochrane CG. J Clin Invest 1988;81:826-833. [PubMed: 3343343]

198. Seeger W, Günther A, Thede C. Am J Physiol 1992;261:L286-L291. [PubMed: 1550251]

199. Wang Z, Gurel O, Baatz JE, Notter RH. J Lipid Res 1996;37:1749-1760. [PubMed: 8864959]

200. Yu SH, Possmayer F. Biochim Biophys Acta 1988;961:337-350. [PubMed: 3401500]

201. Wang Z, Baatz JE, Holm BA, Notter RH. Am J Physiol 2002;283:L897-L906.

202. Walther FJ, Waring AJ, Hernandez-Juviel JM, Gordon LM, Schwan AL, Jung CL, Chang Y, Wang Z, Notter RH. PLoS ONE. 2007in Press

203. Wang Z, Chang Y, Schwan AL, Notter RH. Am J Respir Cell Mol Biol 2007;37:387-394. [PubMed: 17556674]

204. Wang Z, Schwan AL, Lairson LL, O’Donnell JS, Byrne GF, Foye A, Holm BA, Notter RH. Am J Physiol 2003;285:L550-L559. 
205. Notter RH, Schwan AL, Wang Z, Waring AJ. Mini-Rev Med Chem 2007;7:932-934. [PubMed: 17897082]

206. Notter RH, Wang Z, Wang Z, Davy J, Schwan AL. Bioorg Med Chem Lett 2007;17:113-117. [PubMed: 17055273]

207. Chang Y, Wang Z, Schwan AL, Wang Z, Holm BA, Baatz JE, Notter RH. Chem Phys Lipids 2005;137:77-93. [PubMed: 16109391]

208. Kim DK, Fukuda T, Thompson BT, Cockrill B, Hales C, Bonventre JV. Am J Physiol 1995;269:L109-L118. [PubMed: 7631805]

209. Touqui L, Arbibe L. Mol Med Today 1999;5:244-249. [PubMed: 10366819]

210. Vadas P. J Lab Clin Med 1984;104:873-881. [PubMed: 6548766]

211. Vadas P, Pruzanski W. Lab Invest 1986;55:391-404. [PubMed: 3531715]

212. Attalah HL, Wu Y, Alaoui-El-Azher M, Thouron F, Koumanov K, Wolf C, Brochardz L, Harf A, Delclaux C, Touqui L. Eur Respir J 2003;21:1040-1045. [PubMed: 12797501]

213. Nakos G, Kitsiouli E, Hatzidaki E, Koulouras V, Touqui L, Lekka ME. Crit Care Med 2003;33:772779. [PubMed: 15818104]

214. Ackerman SJ, Kwatia MA, Doyle CB, Enhorning G. Chest 2003;123:255S.

215. Karamanoukian HL, Glick PL, Wilcox DL, Rossman JE, Morin FC, Holm BA. J Pediatr Surg 1995;30:1-4. [PubMed: 7722807]

216. Rais-Bahrami K, Rivera O, Seale W, Short B. Crit Care Med 1997;25:1744-1747. [PubMed: 9377892]

217. Gommers D, Hartog A, van’t Veen A, Lachmann B. Crit Care Med 1997;25:1868-1873. [PubMed: 9366772]

218. Zhu GF, Sun B, Niu S, Cai YY, Lin K, Lindwall R, Robertson B. Am J Respir Crit Care Med 1998;158:437-443. [PubMed: 9700118]

219. Hartog A, Gommers D, van't Veen A, Erdmann W, Lachmann B. Adv Exp Med Biol 1997;428:277279. [PubMed: 9500058]

220. Warnecke G, Struber M, Fraud S, Hohlfeld JM, Haverich A. Transplantation 2001;71:1238-1244. [PubMed: 11397956]

221. Zheng S, Zhang WY, Zhu LW, Lin K, Sun B. J Pediatr Surg 2001;36:980-984. [PubMed: 11431761]

222. Sokol GM, Fineberg NS, Wright LL, Ehrenkranz RA. Pediatr Pulmonol 2001;32:14-19. [PubMed: 11416871]

223. Uy IP, Pryhuber GS, Chess PR, Notter RH. Pediatr Crit Care Med 2000;1:107-110. [PubMed: 12813259]

224. Hintz SR, Suttner DM, Sheehan AM, Rhine WD, Van Meurs KP. Pediatrics 2000;106:1339-1343. [PubMed: 11099586]

225. Laterre PF, Wittebole X, Dhainaut JF. Crit Care Med 2003;31(Suppl):S329-S336. [PubMed: 12682461]

226. Greene R. J Thorac Imaging 1986;1:31-38. [PubMed: 3298679]

227. Welty-Wolf KE, Carraway MS, Miller DL, Ortel TL, Ezban M, Ghio AJ, Idell S, Piantadosi CA. Am J Respir Crit Care Med 2001;164:1988-1996. [PubMed: 11734456]

228. Idell S. Am J Respir Crit Care Med 2001;164:517-520. [PubMed: 11520709]

229. Bernard GR, Vincent JL, Laterre PF, LaRosa SP, Dhainaut JF, Lopez-Rodriguez A, Steingrub JS, Garber GE, Helterbrand JD, Ely EW, Fisher CJ Jr. N Engl J Med 2001;344:699-709. [PubMed: 11236773]

230. Nick JA, Coldren CD, Geraci MW, Poch KR, Fouty BW, O’Brien J, Gruber M, Zarini S, Murphy RC, Kuhn K, Richter D, Kast KR, Abraham E. Blood 2004;104:3878-3885. [PubMed: 15339848]

231. van der Poll T, Levi M, Nick JA, Abraham E. Am J Respir Crit Care Med 2005;171:1125-1128. [PubMed: 15750041]

232. Matthay MA, Folkesson HG, Clerici C. Physiol Rev 2002;82:569-600. [PubMed: 12087129]

233. Ware LB, Matthay MA. Am J Respir Crit Care Med 2001;163:1376-1383. [PubMed: 11371404]

234. Calfee CS, Matthay MA. Chest 2007;131:913-920. [PubMed: 17356114] 
235. Basran GS, Hardy JG, Woo SP, Ramasubramanian R, Byrne AJ. Eur J Nucl Med 1986;12:381-384. [PubMed: 2878809]

236. Bonsignore MR, Jerome EH, Culver PL, Dodek PM, Staub NC. J Appl Physiol 1988;64:2647-2652. [PubMed: 2900234]

237. Mutlu GM, Dumasius V, Burhop J, McShane PJ, Meng FJ, Welch L, Dumasius A, Mohebahmadi N, Thakuria G, Hardiman K, Matalon S, Hollenberg S, Factor P. Circ Res 2004;94:1091-1100. [PubMed: 15016730]

238. Sartori C, Allemann Y, Duplain H, Lepori M, Egli M, Lipp E, Hutter D, Turini P, Hugli O, Cook S, Nicod P, Scherrer U. N Engl J Med 2002;346:1631-1636. [PubMed: 12023995]

239. Perkins GD, McAuley DF, Thickett DR, Gao F. Am J Respir Crit Care Med 2006;173:281-287. [PubMed: 16254268]

240. Armstrong L, Millar AB. Thorax 1997;52:442-446. [PubMed: 9176536]

241. Raponi G, Antonelli M, Gaeta A, Bufi M, De Blasi RA, Conti G, D’Errico RR, Mancini C, Filadoro F, Gasparetto A. J Crit Care 1992;7:183-188.

242. Parsons P, Moore F, Ikle D, Henson P, Worthen G. Am Rev Respir Dis 1992;146:694-700. [PubMed: 1519850]

243. Tagan M, Markert M, Schaller M, Feihl F, Chiolero R, Perret C. Am J Med 1991;91(Suppl 3C):7278.

244. Pacht E, Timerman A, Lykens M, Merola A. Chest 1991;100:1397-1403. [PubMed: 1935300]

245. Laurent T, Markert M, Feihl F, Schaller MD, Perret C. Chest 1996;109:163-166. [PubMed: 8549180]

246. Miller EJ, Cohen AB, Matthay MA. Crit Care Med 1996;24:1448-1454. [PubMed: 8797614]

247. Meduri GU, Kohler G, Tolley E, Headley AS, Stentz F, Postlethwaite A. Chest 1995;108:13031314. [PubMed: 7587434]

248. Meduri GU, Healey S, Kohler G, Stentz F, Tolley E, Umberger R, Leeper K. Chest 1995;107:10621073. [PubMed: 7705118]

249. Abraham E, Wunderink R, Silverman H, Perl TM, Nasraway S, Levy H, Bone R, Wenzel RP, Balk R, Alfred R, Pennington JE, Wherry JC. JAMA 1995;273:934-941. [PubMed: 7884952]

250. Tracey KJ, Fong Y, Hesse DG, Manogue KR, Lee AT, Kuo GC, Lowry SF, Cerami A. Nature 1987;330:662-664. [PubMed: 3317066]

251. Cohen J, Carlet J. Crit Care Med 1996;24:1431-1440. [PubMed: 8797612]

252. Abraham E, Anzueto A, Gutierrez G, Tessler S, San Pedro G, Wunderink R, Dal Nogare A, Nasraway S, Berman S, Cooney R, Levy H, Baughman R, Rumbak M, Light RB, Poole L, Allred R, Constant J, Pennington J, Porter S. Lancet 1998;351:929-933. [PubMed: 9734938]

253. Tracey K, Lowry S, Cerami A. Am Rev Respir Dis 1988;138:1377-1379. [PubMed: 3059894]

254. Folkesson HF, Matthay MA, Hebert C, Broaddus CV. J Clin Invest 1995;96:107-116. [PubMed: 7615779]

255. Yokoi K, Mukaida N, Harada A, Watanabe Y, Matsushima K. Lab Invest 1997;76:375-384. [PubMed: 9121120]

256. Broaddus VC, Boylan AM, Hoeffel JM, Kim KJ, Sadik M, Chuntharapai A, Hebert CA. J Immunol 1994;152:2960-2967. [PubMed: 8144895]

257. Adawi A, Zhang Y, Baggs R, Finkelstein J, Phipps RP. Am J Pathol 1998;152:651-657. [PubMed: 9502405]

258. Adawi A, Zhang Y, Baggs R, Rubin P, Williams J, Finkelstein JN, Phipps R. Clin Immunol Immunopathol 1998;89:222-230. [PubMed: 9837692]

259. Fisher CJ, Slotman GJ, Opal SM, Pribble JP, Bone RC, Emmanuel G, Ng D, Bloedow DC, Catalano MA. Crit Care Med 1994;22:12-21. [PubMed: 8124953]

260. Ohlsson K, Bjork P, Bergenfeldt M, Hageman R, Thompson RC. Nature 1990;348:550-552. [PubMed: 2147233]

261. Fisher E, Marano MA, Van Zee KJ, Rock CS, Hawes AS, Thompson WA, DeForge L, Kenney JS, Remick DG, Bloedow DC, Thompson RC, Lowry SF, Moldawer LL. J Clin Invest 1992;89:15511557. [PubMed: 1533231] 
262. Fisher CJ, Dhainaut JFA, Opal SM, Pribble JP, Balk RA, Slotman GJ, Iberti TJ, Rackow EC, Shapiro MJ, Greenman RL. JAMA 1994;271:1836-1843. [PubMed: 8196140]

263. Ziegler EJ, Fisher CJ, Sprung CL, Straube RC, Sadoff JC, Foulke GE, Wortel CH, Fink MP, Dellinger RP, Teng N, Allen IE, Berger HJ, Knatterud GL, LoBuglio AF, Smith CR. N Engl J Med 1991;324:429-436. [PubMed: 1988827]

264. Greenman RL, Schein RMH, Martin MA, Wenzel RP, MacIntyre NR, Emmanuel G, Chmel H, Kohler RB, McCarthy M, Plouffe J, Russell JA. the XOMA Sepsis Study Group. JAMA 1991;266:1097-1102. [PubMed: 1865542]

265. Hoffmann H, Hatherill JR, Crowley J, Harada H, Yonemaru M, Zheng H, Ishizaka A, Raffin TA. Am Rev Respir Dis 1991;143:289-293. [PubMed: 1846727]

266. Sheridan BC, McIntyre RC, Meldrum DR, Fullerton DA. J Surg Res 1997;71:150-154. [PubMed: 9299283]

267. Lindsey HJ, Kisala JM, Ayala A, Lehman D, Hedron CD, Chaudry IH. J Surg Res 1994;56:543548. [PubMed: 8015309]

268. Ishizaka A, Wu ZH, Stephens KE, Horada H, Hogue RS, O’Hanley PT, Raffin TA. Am Rev Respir Dis 1988;138:376-384. [PubMed: 3057964]

269. Law WR, Nadkarni VM, Fletcher MA, Nevola JJ, Eckstein JM, Quance J, McKenna TM, Lee CH, Williams TJ. Circ Shock 1992;37:291-300. [PubMed: 1446387]

270. Fletcher MA, McKenna TM, Owens EH, Nadkarni VM. Circ Shock 1992;36:74-80. [PubMed: 1551188]

271. Mandell GL. Am Rev Respir Dis 1988;138:1103-1105. [PubMed: 3059888]

272. Staudinger T, Presterl E, Graninger W, Locker G, Knapp S, Laczika K, Klappacher G, Stoiser B, Wagner A, Tesinsky P, Kordova H, Frass M. Intensive Care Med 1996;22:888-893. [PubMed: 8905422]

273. Bacher A, Mayer N, Klimscha W, Oismuller C, Steltzer H, Hammerle A. Crit Care Med 1997;25:795-800. [PubMed: 9187598]

274. Staubach KH, Schroder J, Stuber F, Gehrke K, Traumann E, Zabel P. Arch Surg 1998;133:94-100. [PubMed: 9438767]

275. Zeni F, Pain P, Vindimian M, Gay JG, Gery P, Bertrand M, Page Y, Page D, Vermesch R, Bertrand JC. Crit Care Med 1996;24:207-214. [PubMed: 8605790]

276. Lauterbach R, Zembala M. Eur J Pediatr 1996;155:404-409. [PubMed: 8741040]

277. Langley SC, Kelly FJ. Biochem Pharmacol 1993;45:841-846. [PubMed: 8452559]

278. Sastre J, Asensi M, Rodrigo F, Pallardo F, Vento M, Vina J. Life Sci 1994;54:2055-2059. [PubMed: 8208062]

279. Davreux CJ, Soric I, Nathens AB, Watson RWG, McGilvray ID, Suntres ZE, Shek PN, Rotstein OD. Shock 1997;8:432-438. [PubMed: 9421857]

280. Wagner PD, Mathieu-Costello O, Bebaut DE, Gray AT, Natterson PD, Glennow C. Eur Respir J 1989;2:116-126. [PubMed: 2703040]

281. Bernard GR, Lucht WD, Niedermeyer ME, Snapper JR, Ogletree ML, Brigham KL. J Clin Invest 1984;73:1772-1784. [PubMed: 6725559]

282. Leff JA, Wilke CP, Hybertson BM, Shanley PF, Beehler CJ, Repine JE. Am J Physiol 1993;265:L501-L506. [PubMed: 8238538]

283. Suter PM, Domenighetti G, Schaller MD, Laverriere MC, Ritz R, Perret C. Chest 1994;105:190194. [PubMed: 8275731]

284. Jepsen S, Herlevsen P, Knudsen P, Bud MI, Klausen NO. Crit Care Med 1992;20:918-923. [PubMed: 1617983]

285. Bernard GR, Wheeler AP, Arons MM, Morris PE, Paz HL, Russell JA, Wright PA. the Antioxidant in ARDS Study Group. Chest 1997;112:164-172. [PubMed: 9228372]

286. Rosenfeld WN, Davis JM, Parton L, Richter SE, Price A, Flaster E, Kassem N. Pediatrics 1996;97:811-817. [PubMed: 8657519]

287. Fulkerson WJ, Macintyre N, Stamler J, Crapo JD. Arch Intern Med 1996;156:29-38. [PubMed: 8526694] 
288. Davis JM, Rosenfeld WN, Sanders RJ, Gonenne A. J Appl Physiol 1993;74:2234-2241. [PubMed: 8335553]

289. Thompson BT. Crit Care Med 2003;31:S253-257. [PubMed: 12682449]

290. Sessler C, Bloomfield G, Fowler A. Clin Chest Med 1996;17:213-235. [PubMed: 8792062]

291. Hack CE, Aarden LA, Thijs LG. Adv Immunol 1997;66:101-195. [PubMed: 9328641]

292. Meduri GU. Eur Respir J 1996;9:2650-2670. [PubMed: 8980983]

293. Li XY, Donaldson K, Brown D, MacNee W. Am J Respir Cell Mol Biol 1995;13:185-195. [PubMed: 7626286]

294. Windsor AC, Walsh CJ, Mullen PG, Cook DJ, Fisher BJ, Blocher CR, Leeper-Woodford SK, Sugerman HJ, Fowler AA. J Clin Invest 1993;91:1459-1468. [PubMed: 8097206]

295. Goldman G, Welbourn R, Kobzik L, Valeri CR, Shepro D, Hechtman HB. Ann Surg 1990;212:513520. [PubMed: 2222016]

296. Miller EJ, Cohen AB, Nagao S, Griffith DG, Maunder RJ, Martin TR, Weiner-Kronish JP, Sticherling M, Christophers E, Matthay MA. Am Rev Respir Dis 1992;146:427-432. [PubMed: 1489135]

297. Donnelly SC, Strieter RM, Kunkel SL. Lancet 1993;341:643-647. [PubMed: 8095568]

298. Kurdowska A, Carr FK, Stevens MD, Paughman RP, Martin TR. J Immunol 1997;158:1930-1940. [PubMed: 9029135]

299. Goodman RB, Strieter RM, Martin DP, Steinberg KP, Milberg JA, Maunder RJ, Kunkel SL, Walz A, Hudson LD, Martin TR. Am J Respir Crit Care Med 1996;154:602-611. [PubMed: 8810593]

300. Goodman ER, Kleinstein E, Fusco AM, Quinlan DP, Lavery R, Livingstone DH, Deitch EA, Hauser CJ. Arch Surg 1998;13:1234-1239. [PubMed: 9820356]

301. Sempowski G, Chess P, Phipps R. J Immunol 1997;158:4670-1477. [PubMed: 9144479]

302. Fries K, Gaspari A, Blieden T, Looney RJ, Phipps RP. Clin Immunopathol 1995;154:162-170.

303. Sempowski G, Chess P, Padilla J, Moretti A, Phipps R. J Periodontol 1997;68:284-292. [PubMed: 9100204]

304. Barazzone AC, Donati YR, Boccard J, Rochat AF, Vesin C, Kan CD, Piguet PF. Am J Pathol 2002;160:67-71. [PubMed: 11786400]

305. Lechner AJ, Lamprech KE, Potthoff LH, Tredway TL, Matuschak GM. Am J Physiol 1994;266:L561-568. [PubMed: 8203549]

306. Presneill JJ, Harris T, Stewart AG, Cade JF, Wilson JW. Am J Respir Crit Care Med 2002;166:138143. [PubMed: 12119223]

307. Coccia MT, Waxman K, Soliman MH, Tominaga G, Pinderski L. Crit Care Med 1989;17:36-38. [PubMed: 2909319]

308. Ehrly A. J Med 1979;10:331-336. [PubMed: 294470]

309. Stefanovitch V. Res Commun Chem Pathol Pharmacol 1975;10:745-750.

310. Farrukh IS, Gurtner GH, Michael JR. J Appl Physiol 1987;62:47-54. [PubMed: 3031002]

311. Bessler H, Gilgal R, Djaidetti M, Zahavi I. J Leuk Biol 1986;40:747-754.

312. Balibrea-Cantero JL, Arias-Diaz J, Garcia C, Torres-Melero J, Simon C, Rodriguez JM, Vara E. Am J Respir Crit Care Med 1994;149:699-706. [PubMed: 8118639]

313. Zheng H, Crowley JJ, Chan JC, Hoffman H, Hatherill JR, Ishizaka A, Raffin TA. Am Rev Respir Dis 1990;142:1073-1078. [PubMed: 2173454]

314. Sinuff T, Cook DJ, Peterson JC, Fuller HD. J Crit Care 1999;14:1-6. [PubMed: 10102717]

315. Slotman GJ, Burchard KW, D’Arezzo A, Gann DS. J Trauma 1988;28:648-654. [PubMed: 3285017]

316. Yu M, Tomasa G. Crit Care Med 1993;21:1635-1642. [PubMed: 8222677]

317. Network ARDS. JAMA 2000;283:1995-2002. [PubMed: 10789668]

318. Morris PE, Bernard GR. Am J Med Sci 1994;307:119-127. [PubMed: 8141138]

319. Cantin AM, North SL, Hubbard RC, Crystal RG. J Appl Physiol 1987;63:152-157. [PubMed: 3040659]

320. Heffner JE, Repine JE. Am Rev Respir Dis 1989;140:531-554. [PubMed: 2669581]

321. Cantin AM, Bein R. Lung 1991;169:123-138. [PubMed: 1895776] 
322. Cantin AM, Hubbard RC, Crystal RG. Am Rev Respir Dis 1989;139:370-372. [PubMed: 2913886]

323. Gillissen A, Nowak D. Respir Med 1998;92:609-623. [PubMed: 9659525]

324. Chabot F, Mitchell JA, Gutteridge JMC, Evans TW. Eur Respir J 1998;11:745-757. [PubMed: 9596132]

325. Sies, H. Oxidative Stress. Academic Press; London: 1991.

326. Oury T, Chang L, Marklund S, Day B, Crapo J. Lab Invest 1994;70:889-898. [PubMed: 8015293]

327. Marklund SL. Biochem J 1984;222:649-655. [PubMed: 6487268]

328. Nader ND, Davidson BA, Tait AR, Holm BA, Knight PR. Anesth Analg 2005;101:213-219. [PubMed: 15976234]

329. Walther FJ, David-Cu R, Lopez SL. Am J Physiol 1995;269:L613-L617. [PubMed: 7491979]

330. Padmanabhan RV, Gudapaty R, Liener IE, Schwartz BA, Hoidal JR. Am Rev Respir Dis 1985;132:164-167. [PubMed: 4014861]

331. Tanswell A, Freeman B. J Appl Physiol 1987;63:347-352. [PubMed: 3624136]

332. Barnard ML, Baker RR, Matalon S. Am J Physiol 1993;265:L340-L345. [PubMed: 8238368]

333. Walther FJ, Nunex Fl, David-Cu R, Hill KE. Pediatr Res 1993;33:332-335. [PubMed: 8479811]

334. White CW, Jackson JH, Abuchowski A, Kazo GM, Mimmack RF, Berger EM, Freeman BA, McCord JM, Repine JE. J Appl Physiol 1989;66:584-590. [PubMed: 2540139]

335. Davis JM, Rosenfeld WN, Koo HC, Gonenne A. Pediatr Res 1994;35:37-40. [PubMed: 8134197]

336. Gonzalez PK, Zhuang J, Doctrow SR, Malfroy B, Benson PF, Menconi MJ, Fink MP. Shock 1996;6:S23-S26. [PubMed: 8828094]

337. Gonzalez PK, Zhuang J, Doctrow SR, Malfroy B, Benson PF, Menconi MJ, Fink MP. J Pharmacol Exp Ther 1995;275:798-806. [PubMed: 7473169]

338. Gadek JE, DeMichele SJ, Karlstad MD, Pacht ER, Donahoe M, Albertson TE, Van Hoozen C, Wennberg AK, Nelson JL, Noursalehi M. Crit Care Med 1999;27:1409-1420. [PubMed: 10470743]

339. Pacht ER, DeMichele SJ, Nelson JL, Hart J, Wennberg AK, Gadek JE. Crit Care Med 2003;31:491500. [PubMed: 12576957]

340. Beale RJ, Bryg DJ, Bihari DJ. Crit Care Med 1999;27:2799-2805. [PubMed: 10628629]

341. Bernard GR, Luce JM, Sprung CL, Rinaldo JE, Tate RM, Sibbald WJ, Kariman K, Higgins S, Bradley R, Metz CA, Harris TR, Brigham KL. N Engl J Med 1987;317:1565-1570. [PubMed: 3317054]

342. Luce JM, Montgomery AB, Marks JD, Turner J, Metz CA, Murray JF. Am Rev Respir Dis 1988;138:62-68. [PubMed: 3202402]

343. Keel JB, Hauser M, Stocker R, Bauman PC, Speich R. Respiration 1998;65:258-264. [PubMed: 9730790]

344. Hooper RG, Kearl RA. South Med J 1996;89:359-364. [PubMed: 8614872]

345. Biffl WL, Moore FA, Moore EE, Haenel JB, McIntyre RC, Burch JM. Am J Surg 1995;170:591595. [PubMed: 7492007]

346. Meduri GU, Headley AS, Golden E, Carson SJ, Umberger RA, Kelso T, Tolley EA. JAMA 1998;280:159-165. [PubMed: 9669790]

347. Meduri GU, Headley S, Tolley E, Shelby M, Stentz F, Postlewaite A. Chest 1995;108:1315-1325. [PubMed: 7587435]

348. Olivieri D. Respiration 1998;65:256-257. [PubMed: 9841366]

349. Meduri GU. Chest 1999;116:116S-118S. [PubMed: 10424629]

350. Meduri GU, Tolley EA, Chrousos GP, Stentz F. Am J Respir Crit Care Med 2002;165:983-991. [PubMed: 11934726]

351. Steinberg KP, Hudson LD, Goodman RB, Hough CL, Lanken PN, Hyzy R, Thompson BT, Ancukiewicz M. N Engl J Med 2006;354:1671-1684. [PubMed: 16625008]

352. Lauterbach R, Szymura-Oleksiak J. Eur J Pediatr 1999;158:607. [PubMed: 10412826]

353. Ostman A, Heldin CH. Adv Cancer Res 2001;80:1-38. [PubMed: 11034538]

354. Unemori EN, Pickford LB, Salles AL, Piercy CE, Grove BH, Erikson ME, Amento EP. J Clin Invest 1996;98:2739-2745. [PubMed: 8981919] 
355. Tan A, Levrey H, Dahm C, Polunovsky VA, Rubins J, Bitterman PB. Am J Respir Crit Care Med 1999;159:220-227. [PubMed: 9872842]

356. Henke C, Bitterman P, Roongta U, Ingbar D, Polunovsky V. Am J Pathol 1996;149:1639-1650. [PubMed: 8909253]

357. Johnson MA, Kwan S, Snell NJ, Nunn AJ, Darbyshire JH, Turner-Warwick M. Thorax 1989;44:280288. [PubMed: 2669218]

358. Raghu G, Depaso WJ, Cain K, Hammar SP, Wetzel CE, Dreis DF, Hutchinson J, Pardee NE, Winterbauer RH. Am Rev Respir Dis 1991;144:291-296. [PubMed: 1859050]

359. Selman M, Ruiz V, Cabrera S, Segura L, Ramirez R, Barrios R, Pardo A. Am J Physiol 2000;279:L562-L574.

360. Corbel M, Caulet-Maugendre S, Germain N, Molet S, Lagente V, Boichot E. J Pathol 2001;193:538545. [PubMed: 11276015]

361. Weinacker AB, Vaszar LT. Annu Rev Med 2001;52:221-237. [PubMed: 11160776]

362. Olschewski H, Ghofrani HA, Walmrath D, Schermuly R, Temmesfeld-Wollbruck B, Grimminger F, Seeger W. Am J Respir Crit Care Med 1999;160:600-607. [PubMed: 10430735]

363. Veyssier-Belot C, Cacoub P. Cardiovasc Res 1999;44:274-282. [PubMed: 10690304]

364. Kuklin VN, Kirov MY, Evgenov OV, Sovershaev MA, Sjoberg J, Kirova SS, Bjertnaes LJ. Crit Care Med 2004;32:766-773. [PubMed: 15090960] 
Table 1

Potential Biological Targets For Pharmacotherapy In The Acute Exudative Phase Of Ali/Ards

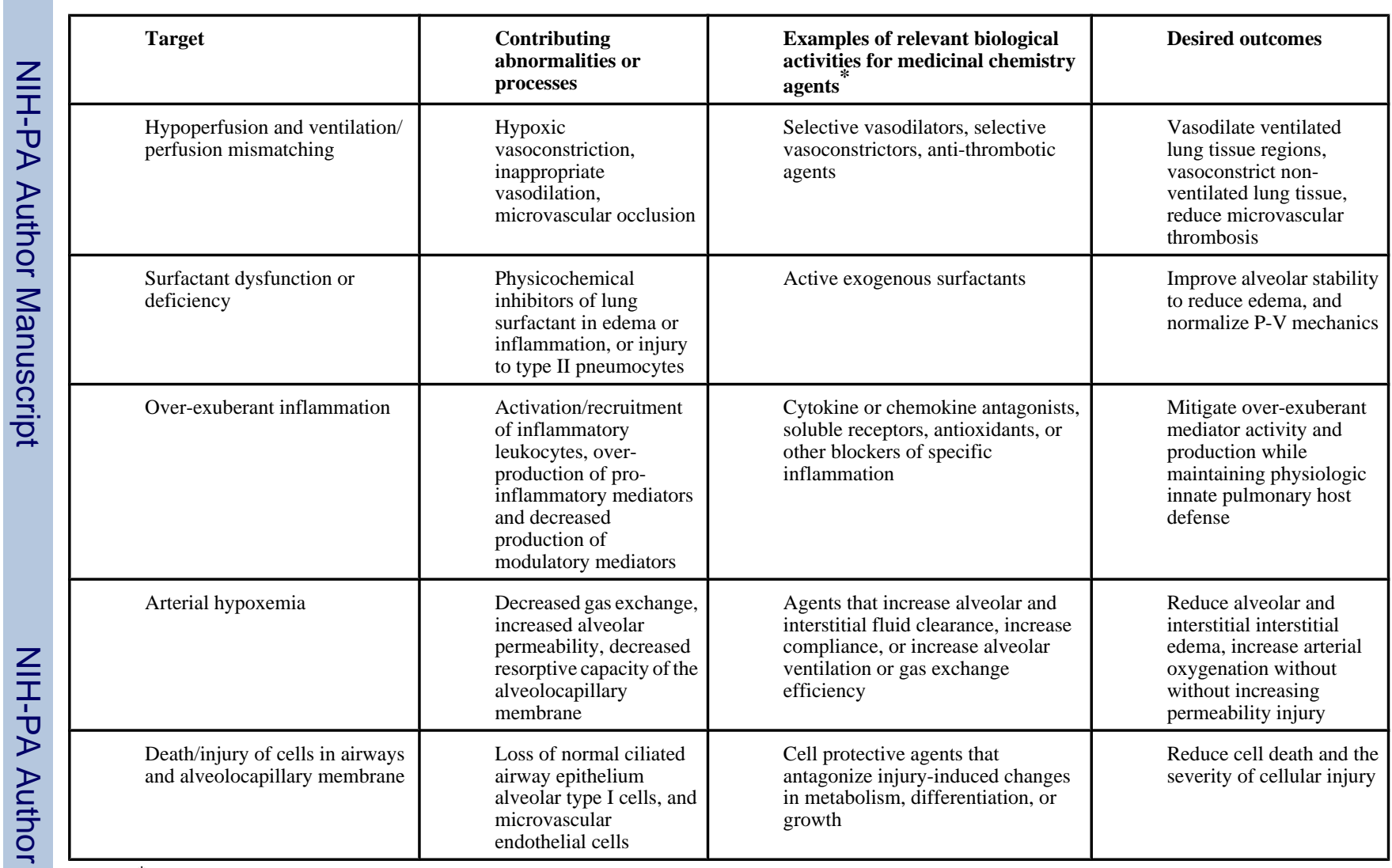

\footnotetext{
* Specific agents of possible utility in single or combination therapies in the acute exudative phase of ALI/ARDS are discussed in the text (Sections IV and $\mathrm{V}$ ). Note that many of the biological targets in Table 1 are interdependent (e.g., surfactant dysfunction contributes to ventilation/perfusion abnormalities, arterial hypoxemia, edema, and abnormal lung mechanics). Similarly, many of the therapies noted will affect overlapping targets (e.g., vasoactive agents, exogenous surfactants, and agents to reduce edema will improve arterial oxygenation, compliance, and ventilation/perfusion mismatching and mitigate cell injury). Adapted from [34].
} 
Table 2

Potential Biological Targets for Pharmacotherapy in Fibroproliferative/Fibrotic Phase ALI/ARDS

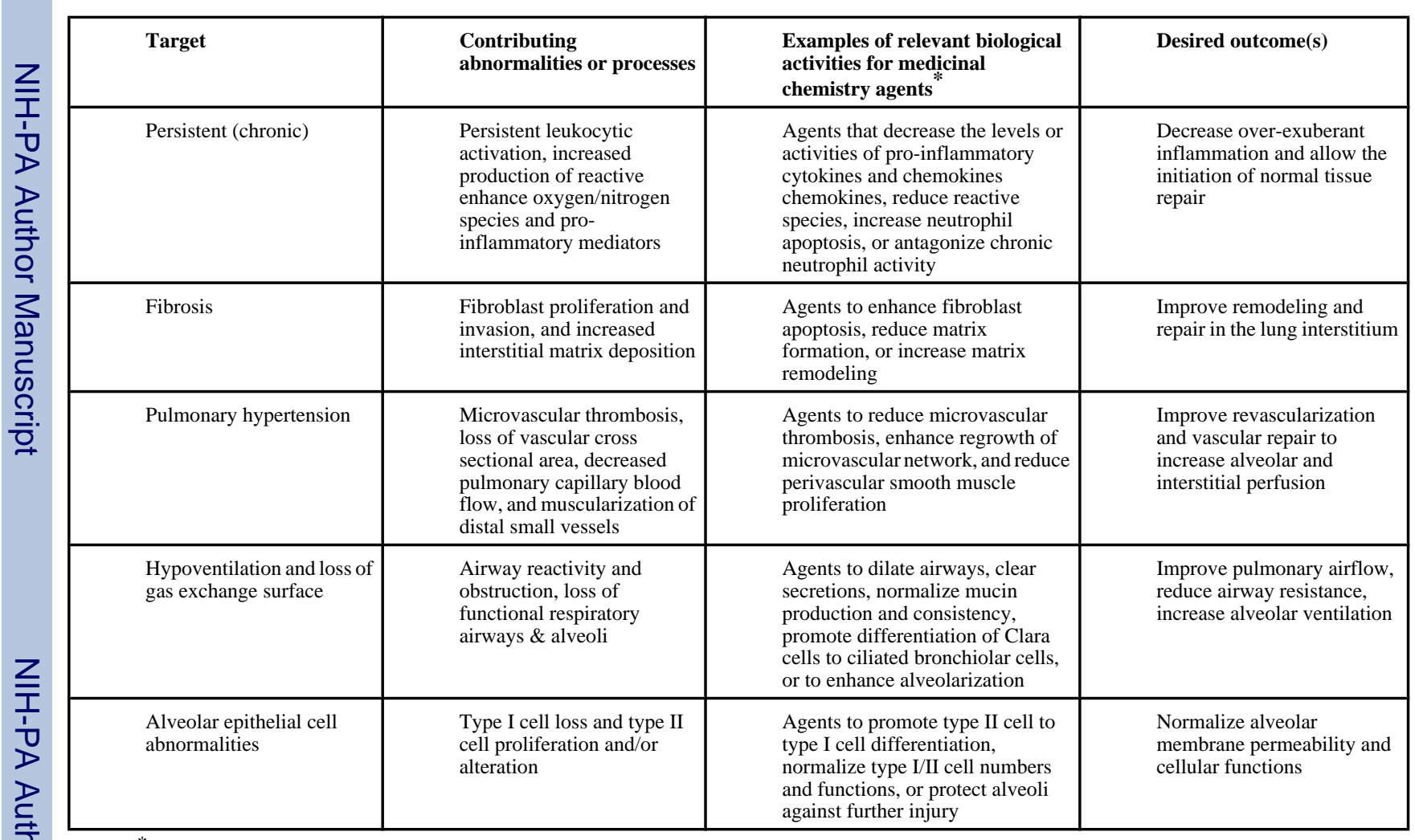

* See text (Section VI) for presentation and discussion of current pharmacologic agents targeting several of the tabulated biological pathways in fibroproliferative phase ALI/ARDS. The development of new and more effective medicinal chemical agents and agent combinations targeting the biological pathways in Tables 1 and 2 for exudative and fibroproliferative phase ARDS is particularly important and challenging, as described in the text. Adapted from [34]. 
Table 3

Examples of Current Pharmacologic Agents with the Potential to Improve Ventilation-Perfusion Matching, Alveolar Ventilation, and Arterial Hypoxemia in ALI/ARDS

Pharmacologic agents to increase perfusion of ventilated alveoli

Inhaled nitric oxide (INO)

Inhaled prostacyclin $\left(\mathrm{PGI}_{2}\right)$

Pharmacologic agents to decrease perfusion of poorly ventilated alveoli

Almitrine

Pharmacologic agents to increase alveolar ventilation and stability

Exogenous surfactants

Pharmacologic agents to reduce vascular obstruction

Anti-coagulants

Tissue factor pathway inhibitor (TFPI)

Site-inactivated factor VIIa

Inhibitors of neutrophil recruitment

Inhibitors of platelet aggregation

Endothelin-1 receptor antagonists

Pharmacologic agents to improve alveolar fluid clearance and reduce edema Beta-2 agonists (e.g., Salbutamol)

See text (Section IV) for specific reference citations to studies using these agents individually in ALI/ARDS, as well as their potential use in combination therapy approaches 
Table 4

Examples of Current Pharmacologic Agents with the Potential to Target Inflammation or Oxidant Injury in Exudative ALI/ARDS

\begin{tabular}{|l|}
\hline Pharmacologic agents with anti-inflammatory effects \\
Anti-TNF- $\alpha$ \\
Anti-IL-8 \\
Anti-CD-40 \\
Pentoxifylline \\
Ketoconazole \\
Pharmacologic agents with anti-oxidant properties \\
N-acetylcysteine \\
Cu, Zn Superoxide dismutase (liposome encapsulated) \\
Nutritional pharmacologic agents \\
Eicosapentaenoic acid \\
Gamma linolenic acid \\
Vitamins E, C
\end{tabular}

See text (Section V) for specific reference citations to studies using these agents individually in ALI/ARDS, as well as their potential use in combination therapy approaches. 
Table 5

Examples of Current Pharmacologic Agents with the Potential to Target Persistent Inflammation, Matrix Deposition, or Improve Pulmonary Blood Flow in the Fibroproliferative Phase of ALI/ARDS

Pharmacologic agents with anti-inflammatory effects

Corticosteroids

Pharmacologic agents affecting matrix deposition and turnover

Anti-TGF $\beta$

Anti-PDGF

Cyclophosphamide

Azothioprine

TIMPs

Pharmacologic agents to improve pulmonary blood flow

Tezosentan

Prostacyclin

Anticoagulants

See text (Section VI) for specific reference citations to studies using these agents individually in ALI/ARDS, as well as their potential use in combination therapy approaches. 